\title{
Potential climate-change impacts on the Chesapeake Bay
}

\author{
Raymond G. Najjar \\ Christopher R. Pyke \\ Mary Beth Adams \\ Denise Breitburg \\ Carl Hershner \\ Virginia Institute of Marine Science
}

See next page for additional authors

Follow this and additional works at: https://scholarworks.wm.edu/vimsarticles

Part of the Climate Commons, and the Oceanography Commons

\section{Recommended Citation}

Najjar, Raymond G.; Pyke, Christopher R.; Adams, Mary Beth; Breitburg, Denise; Hershner, Carl; and et al, Potential climate-change impacts on the Chesapeake Bay (2010). Estuarine, Coastal and Shelf Science, 86, 1-20.

doi: 10.1016/j.ecss.2009.09.026

This Article is brought to you for free and open access by the Virginia Institute of Marine Science at W\&M ScholarWorks. It has been accepted for inclusion in VIMS Articles by an authorized administrator of W\&M ScholarWorks. For more information, please contact scholarworks@wm.edu. 


\section{Authors}

Raymond G. Najjar, Christopher R. Pyke, Mary Beth Adams, Denise Breitburg, Carl Hershner, and et al 
Invited feature

\title{
Potential climate-change impacts on the Chesapeake Bay
}

\author{
Raymond G. Najjar ${ }^{\mathrm{a}, *}$, Christopher R. Pyke ${ }^{\mathrm{b}}$, Mary Beth Adams ${ }^{\mathrm{c}}$, Denise Breitburg ${ }^{\mathrm{d}}$, Carl Hershner ${ }^{\mathrm{e}}$, \\ Michael Kemp ${ }^{f}$, Robert Howarth ${ }^{g}$, Margaret R. Mulholland ${ }^{\mathrm{h}}$, Michael Paolisso ${ }^{\mathrm{i}}$, David Secor ${ }^{\mathrm{j}}$, \\ Kevin Sellner ${ }^{k}$, Denice Wardrop ${ }^{1}$, Robert Wood ${ }^{\mathrm{m}}$
}

\footnotetext{
${ }^{a}$ Department of Meteorology, The Pennsylvania State University, University Park, PA 16802, USA

${ }^{\mathrm{b}}$ US Green Building Council, 2101 L St., NW, Suite 500, Washington, DC 20037, USA

${ }^{\mathrm{c}}$ USDA Forest Service, Timber and Watershed Laboratory, Parsons, WV 26287, USA

${ }^{\mathrm{d}}$ Smithsonian Environmental Research Center, PO Box 28, Edgewater, MD 21037, USA

e Virginia Institute of Marine Science, Rt. 1208, Greate Road, P.O. Box 1346, Gloucester Point, VA 23062, USA

${ }^{\mathrm{f}}$ University of Maryland, Center for Environmental Science, Horn Point Laboratory, P.O. Box 775, Cambridge, MD 21613, USA

${ }^{g}$ Department of Ecology and Evolutionary Biology, Cornell University, E311 Corson Hall, Ithaca, NY 14853, USA

${ }^{\mathrm{h}}$ Department of Ocean, Earth \& Atmospheric Sciences, Old Dominion University, 4600 Elkhorn Avenue, Norfolk, VA 23529-0276, USA

${ }^{\mathrm{i}}$ Department of Anthropology, 1111 Woods Hall, University of Maryland, College Park, MD 20742-7415, USA

j University of Maryland, Center for Environmental Science, Chesapeake Biological Laboratory, 1 William St., Solomons, MD 20688, USA

${ }^{\mathrm{k}}$ Chesapeake Research Consortium, 645 Contees Wharf Road, P.O. Box 28, Edgewater, MD 21037, USA

${ }^{1}$ Penn State Cooperative Wetlands Center, 216 Walker Building, University Park, PA 16802, USA

${ }^{\mathrm{m}}$ Cooperative Oxford Laboratory, NOAA-NCCOS, 904 South Morris Street, Oxford, MD 21654-1323, USA
}

\section{A R T I C L E I N F O}

\section{Article history:}

Received 3 March 2009

Accepted 24 September 2009

Available online 14 October 2009

\section{Regional index terms:}

USA

Mid-Atlantic Region

The Chesapeake Bay

Keywords:

climate

estuaries

circulation

biogeochemistry

vascular plants

fisheries

\begin{abstract}
A B S T R A C T
We review current understanding of the potential impact of climate change on the Chesapeake Bay. Scenarios for $\mathrm{CO}_{2}$ emissions indicate that by the end of the $21^{\text {st }}$ century the Bay region will experience significant changes in climate forcings with respect to historical conditions, including increases in $\mathrm{CO}_{2}$ concentrations, sea level, and water temperature of $50-160 \%, 0.7-1.6 \mathrm{~m}$, and $2-6{ }^{\circ} \mathrm{C}$, respectively. Also likely are increases in precipitation amount (very likely in the winter and spring), precipitation intensity, intensity of tropical and extratropical cyclones (though their frequency may decrease), and sea-level variability. The greatest uncertainty is associated with changes in annual streamflow, though it is likely that winter and spring flows will increase. Climate change alone will cause the Bay to function very differently in the future. Likely changes include: (1) an increase in coastal flooding and submergence of estuarine wetlands; (2) an increase in salinity variability on many time scales; (3) an increase in harmful algae; (4) an increase in hypoxia; (5) a reduction of eelgrass, the dominant submerged aquatic vegetation in the Bay; and (6) altered interactions among trophic levels, with subtropical fish and shellfish species ultimately being favored in the Bay. The magnitude of these changes is sensitive to the $\mathrm{CO}_{2}$ emission trajectory, so that actions taken now to reduce $\mathrm{CO}_{2}$ emissions will reduce climate impacts on the Bay. Research needs include improved precipitation and streamflow projections for the Bay watershed and whole-system monitoring, modeling, and process studies that can capture the likely non-linear responses of the Chesapeake Bay system to climate variability, climate change, and their interaction with other anthropogenic stressors.
\end{abstract}

(c) 2009 Elsevier Ltd. All rights reserved.

\section{* Corresponding author.}

E-mail addresses: najjar@meteo.psu.edu (R.G. Najjar), cpyke@usgbc.org (C.R Pyke),mbadams@fs.fed.us (M.B. Adams), breitburgd@si.edu (D. Breitburg),carl@ sweethall.wetlan.vims.edu (C. Hershner), kemp@hpl.umces.edu (M. Kemp),rwh2@ cornell.edu (R. Howarth), mmulholl@odu.edu (M.R. Mulholland), mpaolisso@anth. umd.edu (M. Paolisso), secor@cbl.umces.edu (D. Secor), sellnerk@si.edu (K. Sellner) dhw110@psu.edu (D. Wardrop), Bob.Wood@noaa.gov (R. Wood).

\section{Introduction}

Estuarine ecosystems are vulnerable to human activities that lead to nutrient pollution (and consequent eutrophication), excess or insufficient sedimentation, dredging, river water diversion, and other types of pollution (UNEP/GPA, 2006). Estuaries are also particularly vulnerable to climate change because they can respond to at least three different types of forcing: (1) streamflow quality and quantity; (2) air-water fluxes of $\mathrm{CO}_{2}$, heat, freshwater (i.e., evaporation and precipitation) and momentum (i.e., wind stress); and (3) fluctuations in sea level and other ocean properties. With 
climate change due to human activity well underway (IPCC, 2007), there is a need to assess the impacts of climate change on estuaries.

The goal of this paper is to review and synthesize the scientific literature on climate change impacts on the Chesapeake Bay (Fig. 1), one of the largest and most productive estuaries in the world (National Oceanic and Atmospheric Administration, 1990). In 2000, commercial fisheries landings for the Chesapeake Bay exceeded U.S. $\$ 172$ million, accounting for $5 \%$ of the value of all United States fisheries (National Marine Fisheries Service, 2001). Although these figures are significant, they understate the value of the Chesapeake Bay and its fisheries because they do not account for the ecological and recreational services the Bay provides to the food web and fisheries of the North American Atlantic Coast.

In this review, we follow a logical progression from changes in climatic and hydrological forcing factors (Section 2), to changes in watershed fluxes of nutrients and sediment (Section 3) and physical (Section 4) and biogeochemical (Section 5) conditions in the Bay. Impacts on Bay living resources-vascular plants (Section 6) and fish and shellfish (Section 7)-are then considered before summarizing our findings and providing general recommendations for further study (Section 8). Our synthesis builds on a number of reviews discussing the impact of climate change on ecosystems, coastal areas and marine resources of the mid-Atlantic region (Boesch, 2008; Moore et al., 1997; Moss et al., 2002; Najjar et al., 2000; Rogers and McCarty, 2000; Wood et al., 2002), the United States (Field et al., 2001; Scavia et al., 2002), and the World (Kennedy et al., 2002).

Statistically rigorous forecast probabilities are not possible at this time for climate change and its impacts in the Chesapeake Bay region. By using expert judgment, however, we believe that we can defensibly assign rough probabilities regarding the direction of many changes. To maintain consistency throughout this paper, we use the following terminology (Manning, 2006) to express probability ranges: virtually certain (>99\%), very likely (90-99\%), and likely (66-90\%).

\section{Climatic and hydrologic processes affecting the bay}

\subsection{Atmospheric composition}

Being a well-mixed gas in the atmosphere, regional and global projections of atmospheric $\mathrm{CO}_{2}$ are essentially identical. Projections for global mean atmospheric $\mathrm{CO}_{2}$ concentration over the next 100 years vary widely, mainly because of the uncertainty in future $\mathrm{CO}_{2}$ emissions (Fig. 2), but also because of poorly understood feedbacks between climate and the carbon cycle. However, it is virtually certain that $\mathrm{CO}_{2}$ levels will continue to increase throughout the $21^{\mathrm{st}}$ century. Surface water $\mathrm{CO}_{2}$ changes are expected to closely track atmospheric $\mathrm{CO}_{2}$ changes, leading to a decrease in $\mathrm{pH}$ and carbonate ion concentration, $\left[\mathrm{CO}_{3}^{2-}\right]$, which is expected to harm $\mathrm{CaCO}_{3}$-secreting organisms, including shellfish. Orr et al. (2005) showed that $\left[\mathrm{CO}_{3}^{2-}\right]$ and $\mathrm{pH}$ decreases averaging about $10 \%$ and 0.1 , respectively, have already taken place throughout the surface ocean due to the invasion of anthropogenic $\mathrm{CO}_{2}$. Under a greenhouse gas scenario similar to the Intergovernmental Panel on Climate Change's (IPCC's) A2 storyline (Fig. 2), these changes increase to $45 \%$ and 0.5 , respectively, by 2100 .

\subsection{Water temperature}

Fig. 3 shows $20^{\text {th }}$-century surface water temperature variability measured at two locations in the Chesapeake Bay. High variability is superimposed on a long-term warming; the 1990s were about $1^{\circ} \mathrm{C}$ warmer than the 1960s. Fig. 3 also shows an estimate of surface water temperature averaged over the mainstem Bay based on data from the Chesapeake Bay Water Quality Monitoring Program,

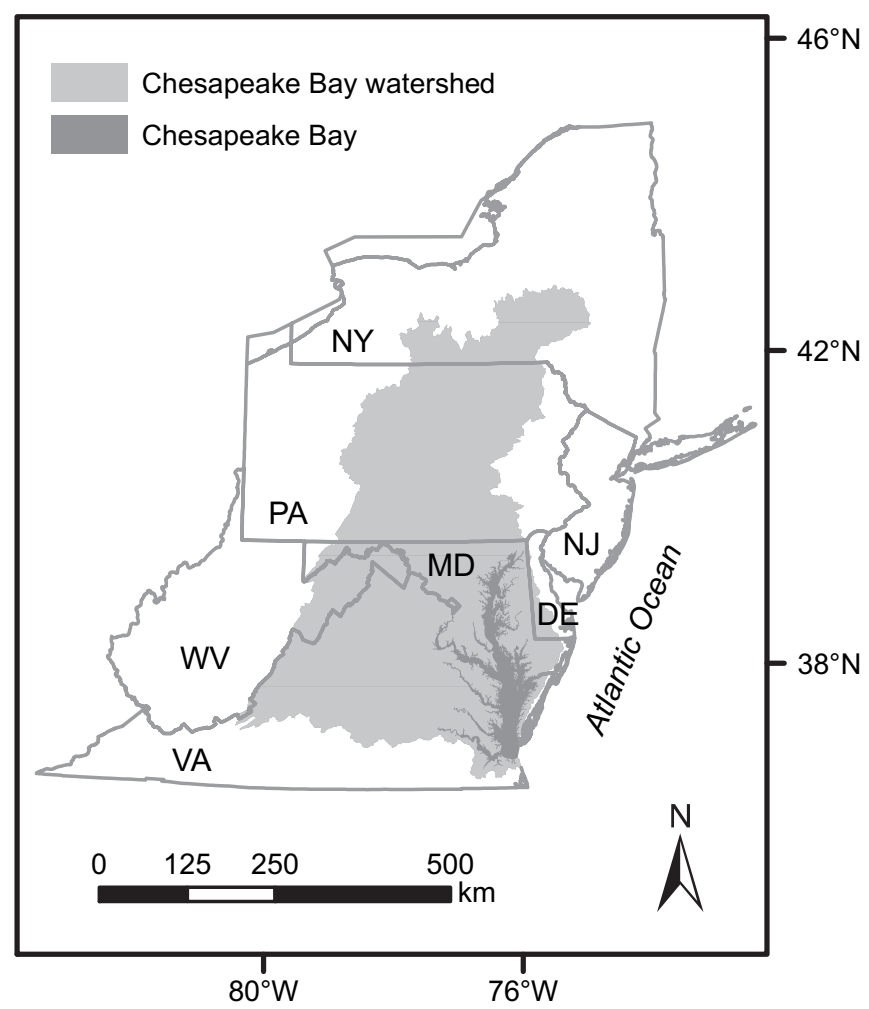

Fig. 1. Map of the Chesapeake Bay, its watershed, and the states in its watershed.

which sampled the water column at least monthly at several dozen stations throughout the mainstem Bay since 1984. The correspondence between the pier data and the Bay-average data during the period of overlap indicates that the longer time series measured at the piers reflect mean Bay temperature quite well.

Numerous studies have documented a positive correlation between water temperature in the Bay and regional atmospheric and oceanic temperature at time scales ranging from monthly to decadal (e.g., Cronin et al., 2003; Preston, 2004). It is therefore very likely that the regional temperature projections made from climate models can be accurately applied to the Bay.

Two recent studies have analyzed the output of global climate models (GCMs) in the Chesapeake Bay region (Hayhoe et al., 2007; Najjar et al., 2009). Both studies found the multi-model average to capture the $20^{\text {th }}$-century warming trend of the northern portion of the Chesapeake Bay watershed; but the weak cooling observed in its southern portion (e.g., Allard and Keim, 2007) is not found in models (Najjar et al., 2009). The degree of projected warming differs greatly among models (Fig. 4) and scenario (Fig. 5), but it is nevertheless very likely that temperature will continue to increase throughout the $21^{\text {st }}$ century. Model-averaged projections in Najjar et al. (2009) for the six scenarios shown in Fig. 2 range from 3 to $6{ }^{\circ} \mathrm{C}$ warming by 2070-2099 (Fig. 5a). When the best-performing models are used, the projected warming decreases to $2-5^{\circ} \mathrm{C}$ (Fig. 5c). Similar projections were found by Hayhoe et al. (2007).

Changes in temperature extremes can be as important as annual mean temperature changes. Meehl et al. (2007) analyzed the output of nine global climate models for changes in heat waves, defined as "the longest period in the year of at least five consecutive days with maximum temperature at least $5{ }^{\circ} \mathrm{C}$ higher than the climatology of the same calendar day." Under the A1B scenario (Fig. 2), heat waves along the east coast of North America, including the Mid-Atlantic, are projected to increase by more than two standard deviations by the end of the $21^{\text {st }}$ century. 


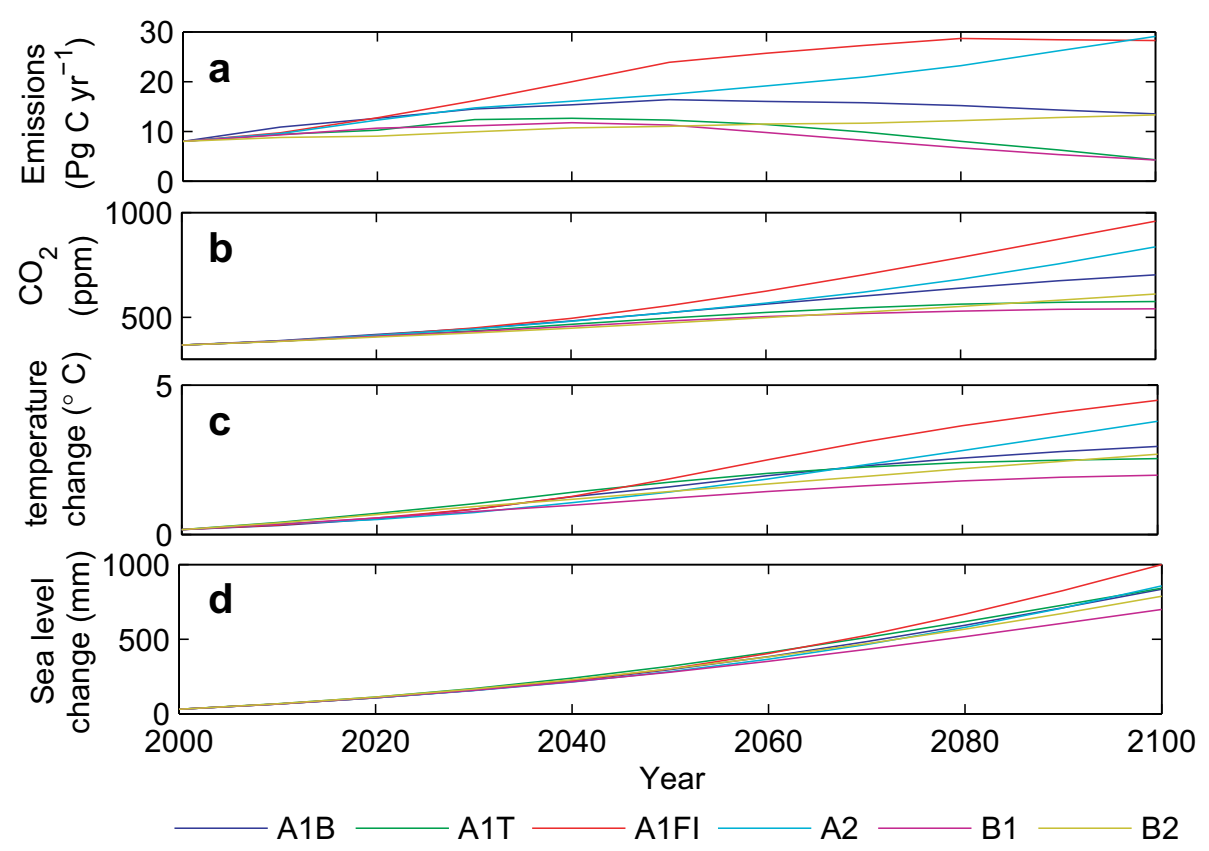

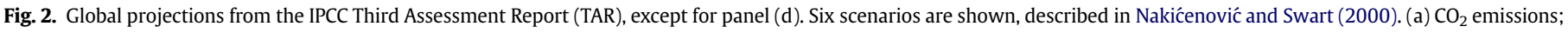

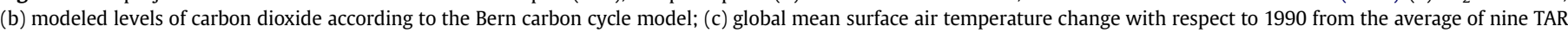

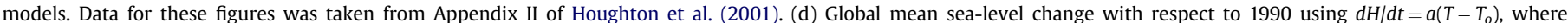

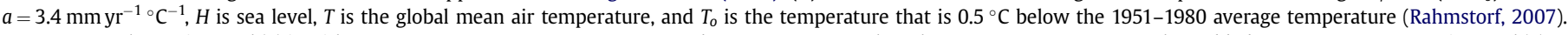

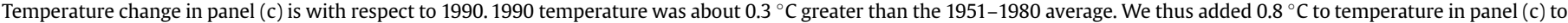
get $T-T_{0}$. This gives $d H / d t$ for 1990 of $1.7 \mathrm{~mm} \mathrm{yr}^{-1}$, which is within the error of the observed rate (Church et al., 2004).

\subsection{Precipitation}

Climate models have similar Bay-region precipitation predictions under enhanced greenhouse gas levels: (1) multi-model averages of more annual precipitation (Fig. 5c and d), (2) a wide spread among models of annual precipitation change (Fig. 4), and (3) high consensus among the models in winter and spring, when precipitation is projected to increase (Fig. 4). The wide spread in modeled

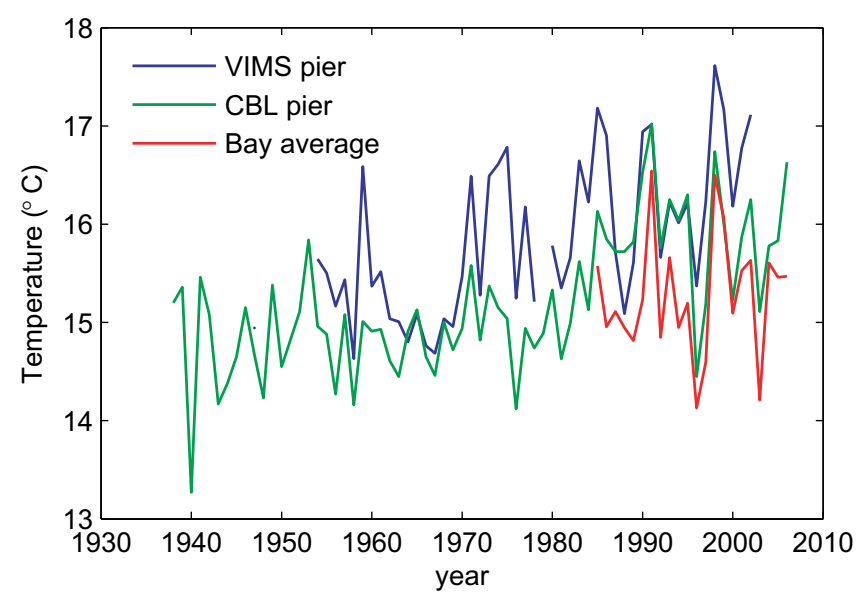

Fig. 3. Annual average surface temperature from the mouth of the York River (VIMS pier), the mouth of the Patuxent River (CBL pier), and average throughout the mainstem Bay (Bay average). VIMS pier data were reported in Austin (2002) and CBL pier data were reported in Kaushal et al. (in press). VIMS pier data are part of the VIMS Scientific Data Archive, and were acquired from Gary Anderson, Virginia Institute of Marine Science, School of Marine Science, College of William \& Mary, Gloucester Point, Virginia. Bay average temperature was computed by David Jasinski, Chesapeake Bay Program Office, using surface temperature measurements from the Chesapeake Bay Water Quality Monitoring Program. Data were first average by month at each station, then by year, before taking arithmetic mean of all stations. annual precipitation changes reflects the Mid-Atlantic region's position at the boundary between subtropical precipitation decreases and subpolar precipitation increases; consensus increases for the winter results as this boundary moves south (Meehl et al., 2007). The difficulty that climate model have had in capturing longterm trends in precipitation the Northeast U.S. (Hayhoe et al., 2007; Najjar et al., 2009)-mainly increasing and particularly in extreme wet events (Groisman et al., 2001, 2004)-may also be due to its location.

An important characteristic of precipitation is its intensity, particularly for watershed export of sediment and phosphorus (Section 3.1). Defined as the annual mean precipitation divided by the number of days with rain, precipitation intensity in the MidAtlantic region is expected to increase under the A1B scenario (Fig. 2) by one standard deviation by the end of the $21^{\text {st }}$ century (Meehl et al., 2007). This increase was found to be a result of an increase in annual precipitation as well as the number of dry days, a finding consistent with changes in storm frequency and intensity (Section 2.6).

\subsection{Streamflow}

Much of the interannual variability in streamflow to the Bay is driven by precipitation, with a relatively small role for evapotranspiration (e.g., Najjar, 1999). The Northeast U.S., including the Chesapeake Bay watershed, has been characterized as a region of increasing streamflow, particularly in extreme wet events, consistent with the precipitation trends (Groisman et al., 2001, 2004).

Previous hydrological modeling studies found widely varying streamflow projections in the Northeast U.S. - from $-40 \%$ to $+30 \%$ for roughly a doubling of atmospheric $\mathrm{CO}_{2}$ (summarized in Najjar et al., 2009)-even when forced by the same climate models (Neff et al., 2000; Wolock and McCabe, 1999). The discrepancy in future projections is most likely due to different modeled evapotranspiration 


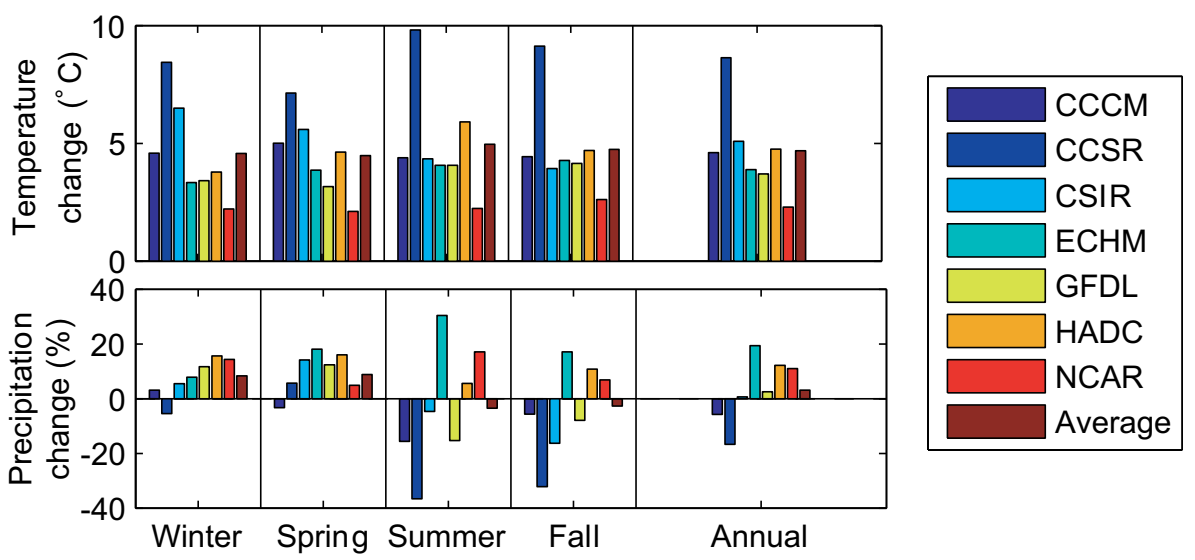

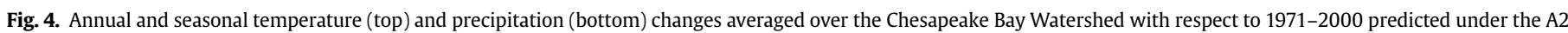
scenario for the period 2070-2099 (after Najjar et al., 2009).

responses (and therefore streamflow responses) to temperature change. This divergence is probably due to the lack of an observational record of substantial temperature change with which to constrain hydrological models. For example, the standard deviation of annual air temperature over the Chesapeake Bay Watershed is $0.5^{\circ} \mathrm{C}$ (Najjar et al., 2009), which is small compared with the multi-model mean projected 100-year warming (Fig. 5). Other confounding influences on streamflow, which are generally not considered in future projections, include vegetation changes, the direct influence of $\mathrm{CO}_{2}$ on evapotranspiration, and land use and land cover change.

The seasonality of streamflow to the Chesapeake Bay is extremely important because it helps to regulate the timing of the spring phytoplankton bloom and is also very important in regulating nutrient delivery to the Bay (Section 5.1). Hydrological model simulations by Hayhoe et al. (2007) in the U.S. Northeast predict greater wintertime flows (due both to snow melt and more rain rather than snow) and depressed summer flows (due to increased evapotranspiration and also less groundwater recharge during the spring snowmelt period). They also predict an advance of the spring streamflow peak of nearly 2 weeks. January-May average flow of the Susquehanna River is a significant predictor of summertime circulation and biogeochemistry (Hagy, 2002; Hagy et al., 2004). Historically, there is a strong correlation between January-May flow and precipitation in the Susquehanna River Basin such that fractional flow increases are equal to fractional precipitation increases (Najjar, 2009). Given the consensus among models regarding spring and winter precipitation increases, it is likely that January-May flow of the Susquehanna River will increase in the future.
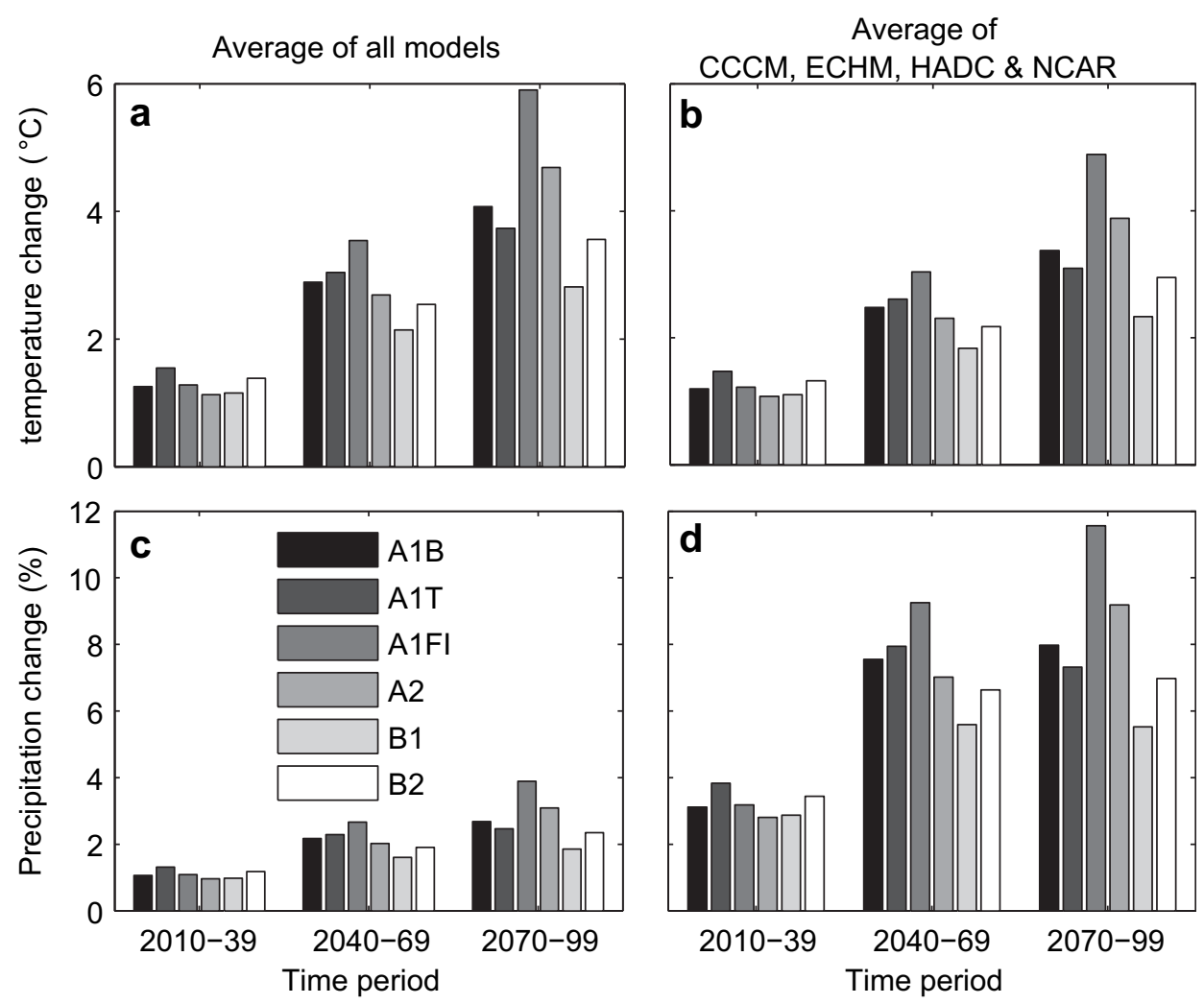

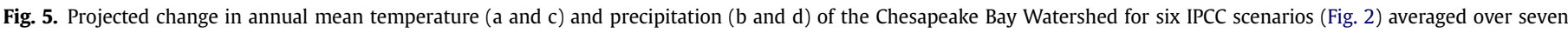
climate models ( $\mathrm{a}$ and b) and the four ranked highest (c and d) (reproduced from Najjar et al., 2009). 
Due to projections of a greater number of precipitation-free days and greater evapotranspiration (resulting from higher temperatures) in the Bay watershed, drought is expected to increase in the future. Defining drought as a $10 \%$-or-more deficit of monthly soil moisture relative to the climatological mean, Hayhoe et al. (2007) simulated increases in droughts of different durations over the Northeast U.S. For example, the number of short-term (1-3 months) droughts was projected to increase $24-79 \%$ (based on the B1 \& A1FI greenhouse gas scenarios, see Fig. 2) by 2070-2099 with respect to 1961-1990. Medium (3-6 months) and long (>6 months) droughts had even larger fractional increases.

\subsection{Sea level}

Tide gauge measurements reveal a steady increase in sea level throughout the Chesapeake Bay during the $20^{\text {th }}$ century (Fig. 6). Global-mean sea surface height increased at a rate of $1.8 \pm 0.3 \mathrm{~mm} \mathrm{yr}^{-1}$ over the second half of the $20^{\text {th }}$ century (Church et al., 2004), substantially smaller than Chesapeake Bay rates, which range from 2.7 to $4.5 \mathrm{~mm} \mathrm{yr}^{-1}$ (average $3.5 \mathrm{~mm} \mathrm{yr}^{-1}, n=6$ ) (Zervas, 2001), a difference most likely due to long-term subsidence (Davis and Mitrovica, 1996). Rahmstorf (2007) developed a semi-empirical approach that predicts global sea-level increases of 700 to $1000 \mathrm{~mm}$ by 2100 for a range of scenarios spanning B1 to A1FI (Fig. 2d). Allowing for errors in the climate projections and in the semi-empirical model, the projected range increases to 500 to $1400 \mathrm{~mm}$. If we add a Chesapeake Bay local component of $2 \mathrm{~mm} \mathrm{yr}^{-1}$ to this, we obtain sea-level increases of approximately 700 to $1600 \mathrm{~mm}$ by 2100 , a projection we consider to be very likely.

Sea-level variability is very likely to increase in the future. As noted below (Section 4.1), the tidal range is likely to increase as a result of increases in mean sea level in the Bay. Further, increases in extreme wave heights will accompany the likely increases in intense storms, both tropical and extratropical, discussed next.

\subsection{Storms}

Tropical cyclones and extratropical winter cyclones have had dramatic and long-lasting effects on the Chesapeake Bay. For example, $50 \%$ of all the sediment deposited in the Northern Chesapeake Bay between 1900 and the mid-1970s was due to Tropical Storm Agnes (June 1972) and the extratropical cyclone associated with the Great Flood of (March) 1936 (Hirschberg and Schubel, 1979).

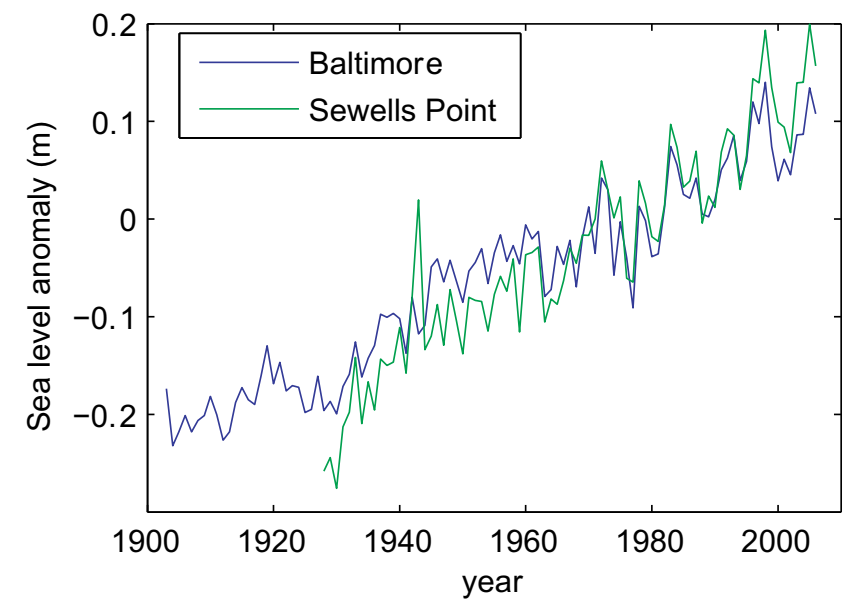

Fig. 6. Long-term sea-level change at two locations in the Chesapeake Bay: Baltimore, MD (upper bay) and Sewells Point, VA (lower bay). Data are annual mean differences from the 1950-2000 average and were acquired from NOAA's Center for Operational Oceanographic Products and Services.
Trenberth et al. (2007) summarized recent studies on tropical cyclone trends, noting a significant upward trend globally in their destructiveness since the 1970s, which is correlated with sea surface temperature. Christensen et al. (2007) and Meehl et al. (2007) summarized future projections in tropical cyclones, concluding that it is likely that peak wind intensities will increase.

Past and future trends in extratropical cyclones are fairly clear at the hemispheric scale but not at the regional scale. There is good evidence that mid-latitude winter storm frequency decreased and intensity increased over the second half of the $20^{\text {th }}$ century (e.g., Paciorek et al., 2002). However, an analysis of U.S. East Coast extratropical winter storms showed no significant trend in frequency and a marginally significant decline in intensity (Hirsch et al., 2001). Lambert and Fyfe (2006) showed remarkable consistency among GCMs in the future projections of winter extratropical cyclone activity. For the A1B scenario (see Fig. 2), the multi-model means over the Northern Hemisphere are a $7 \%$ decrease in frequency of all extratropical winter cyclones and $19 \%$ increase in intense extratropical winter cyclones, comparing the 2081-2100 period to the 1961-2000 period. In a study focused on North America, Teng et al. (2007) tentatively suggested that cyclone frequency in the Northeast U.S. will decrease.

\section{Fluxes of nutrients and sediment from the watershed}

The fluxes of sediments and nutrients from the landscape have been profoundly affected by climate variability, and so it is reasonable to expect that future climate change will alter material fluxes to the Bay. Most of the nutrient inputs to the Chesapeake Bay come from non-point sources such as agriculture and atmospheric deposition. In this section we address non-point source (NPS) sediment and nutrient pollution, with particular emphasis on atmospheric deposition because of the large uncertainties involved. We also consider how climate change may influence the roles of wetlands and point sources in nutrient loading to the Bay.

\subsection{Non-point pollution by sediments and phosphorus}

Because most NPS phosphorus pollution is particle bound, the controls on sources and fluxes of sediments and phosphorus are similar (e.g., Sharpley et al., 1995). The major control on NPS sediment and phosphorus pollution is the rate of erosion, which is influenced by the interaction of land-use patterns and climate (e.g., Meade, 1988). Erosion rates from forest ecosystems are quite low whereas erosion from agricultural and developed lands can be very high (Swaney et al., 1996). Erosion occurs when water flows over these surfaces, and that in turn occurs when soils are saturated with water or during major precipitation or snowmelt events.

Annual sediment loading to the Chesapeake Bay is a non-linear function of annual streamflow (Fig. 7), indicating an increase in total suspended sediment concentration as flow increases, which likely results from enhanced erosion and resuspension of sediments in the streambed. Even if the mean discharge were to remain unchanged, erosion could increase if the precipitation intensity were to increase, a projection that is more certain than annual streamflow changes (Sections 2.3 and 2.4). To date, there has been little if any testing of how various climate change scenarios may affect erosion in the watersheds of the Chesapeake Bay.

NPS phosphorus pollution is a function of the amount of phosphorus associated with eroded soils in addition to the rate of erosion. Agricultural soils are elevated in phosphorus compared to forest soils because of the addition of inorganic fertilizers and manure (e.g., Sharpley et al., 1995). Not only can erosion of these Prich agricultural soils be a major source of phosphorus pollution, but the problem remains as agricultural lands are converted into 


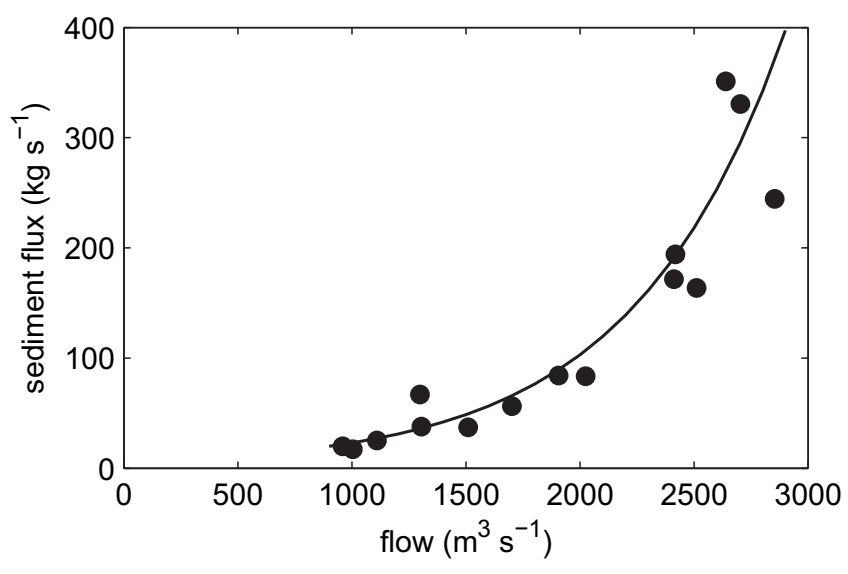

Fig. 7. Relationship between annual sediment yield and total freshwater inflow to the Chesapeake Bay for the years 1990 to 2004 . The curve is a least-squares exponential fit $\left(r^{2}=0.93\right): y=5.13 e^{0.0015 x}$. The estimates were obtained from the Chesapeake Bay Program web site. The annual sediment yields were computed by the United States Geological Survey by summing the products of daily streamflow and riverine Total Suspended Solids (TSS) concentrations. The TSS concentrations are based on a statistical model calibrated with TSS observations from several monitoring stations. Details on the data sources and methodology are given in Langland et al. (2006, pg. 13).

suburban landscapes; phosphorus losses can be particularly great from erosion at construction sites when the soils are former agricultural soils, and even storm water retention ponds and wetlands can be major sources of NPS phosphorus pollution if the systems are constructed with P-rich soils (Davis, 2007).

\subsection{Non-point pollution by nitrogen}

Nitrogen NPS pollution is controlled by an interaction of nitrogen inputs to the landscape and climate. For many large watersheds in the temperate zone, including the major tributary rivers of the Chesapeake Bay, the average export flux of nitrogen from a watershed is $20-25 \%$ of the net anthropogenic nitrogen inputs (NANI) to the watershed, where NANI is defined as the use of synthetic nitrogen fertilizer, nitrogen fixation associated with agro-ecosystems, atmospheric deposition of oxidized forms of nitrogen $\left(\mathrm{NO}_{\mathrm{y}}\right)$, and the net input of nitrogen in foods and feeds for humans and for animal agriculture (e.g., Boyer and Howarth, 2008). However, the percentage of NANI that is exported out of a watershed in rivers is related to climate. For example, Boynton and Kemp (2000) showed that years with high runoff resulted in enhanced nutrient export from the Chesapeake Watershed. Castro et al. (2003) modeled nitrogen fluxes to the major estuaries of the United States, including the Chesapeake Bay, as a function of NANI, land use, and climate. Their models suggested that land use is a very important factor in determining export of NANI, with greater export from urban and suburban landscapes and much lower export from forests, and that land use and climate may interact strongly.

Howarth et al. (2006) compared the average percentage export of NANI across 16 major river basins in the northeastern U.S. (Fig. 8). In the watersheds where precipitation and river discharge is greater, the percentage of NANI that flows downriver to coastal ecosystems is up to $40-45 \%$, while in drier regions only $10-20 \%$ is exported over long-term periods. Howarth et al. (2006) attributed this to sinks of nitrogen in the landscape, with less denitrification in the wetter watersheds due to lower water residence times in wetlands and loworder (i.e., headwater) streams. Given the climate change predictions for increased precipitation presented by Najjar et al. (2000), and assuming no change in NANI or land use, Howarth et al. (2006) predicted an increase in nitrogen flux down the Susquehanna River of $17 \%$ by 2030 and $65 \%$ by 2095 (associated with precipitation
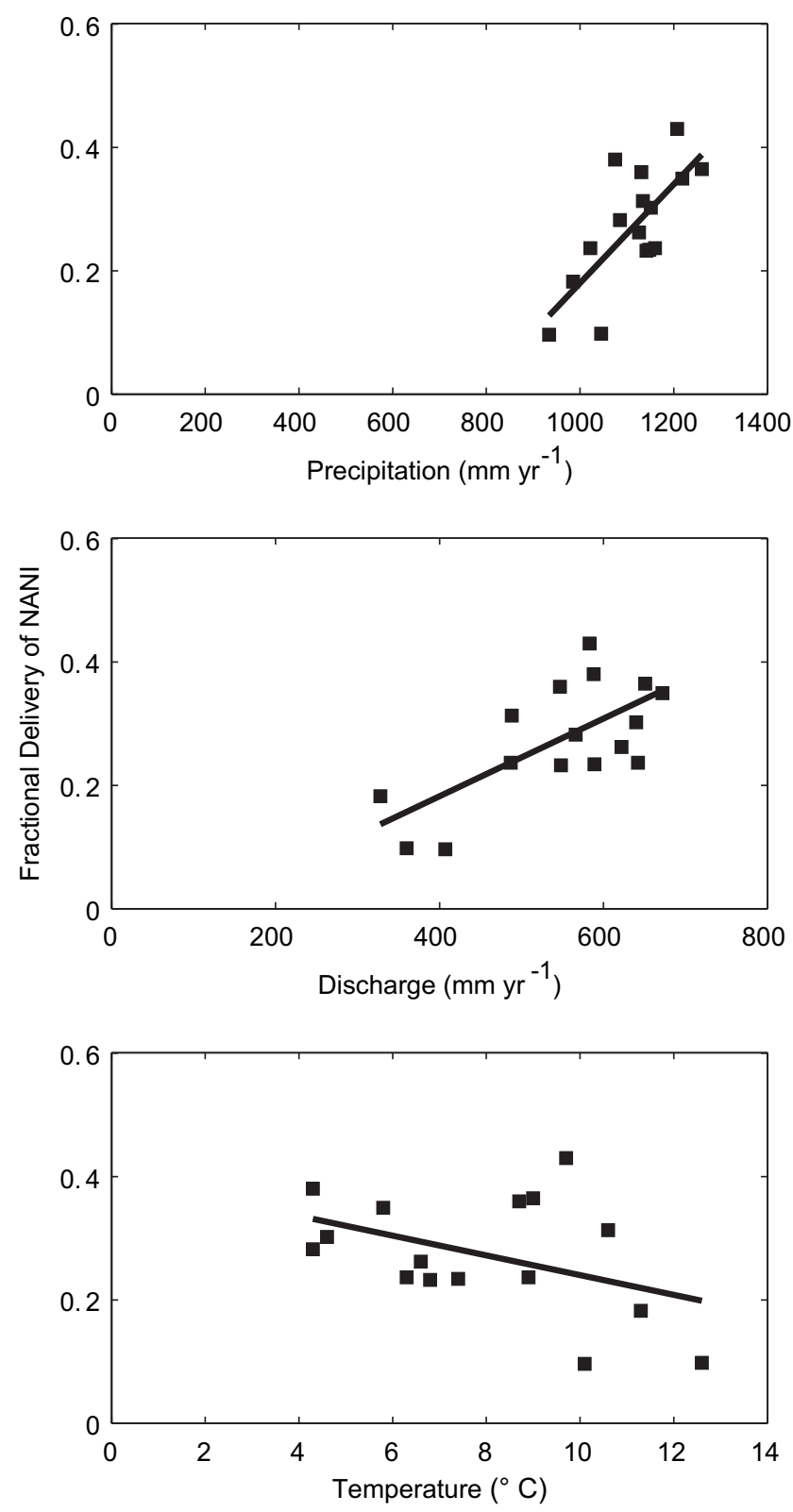

Fig. 8. The fractional delivery of net anthropogenic nitrogen inputs (NANI) for 16 major watersheds in the northeastern United States plotted as a function of mean discharge, mean precipitation, and mean temperature. The relationship for discharge and precipitation are highly significant ( $p=0.003$ and 0.0015 respectively); the relationship for temperature is weaker $(p=0.11$ ) (reprinted from Howarth et al., 2006).

increases of $4 \%$ and $15 \%$, respectively). More updated precipitation projections for the Susquehanna River Basin (e.g., Fig. 4; Hayhoe et al., 2007; Najjar et al., 2009) would yield similar results.

Schaefer and Alber (2007) expanded on the analysis of Howarth et al. (2006) by including data from the major watersheds in the southeastern U.S. This larger data set showed a significant influence of temperature, with low percentage export of NANI at high temperatures and a greater percentage export of NANI at low temperatures. Schaefer and Alber (2007) attributed the temperature effect on export to act through denitrification, with warmth favoring higher rates. The significant correlation with temperature observed by Schaefer and Alber (2007) is driven by the large temperature difference between the northeastern and southeastern regions. Other controlling factors such as soil types may be at play across this larger data set. If temperature is the major factor controlling the 


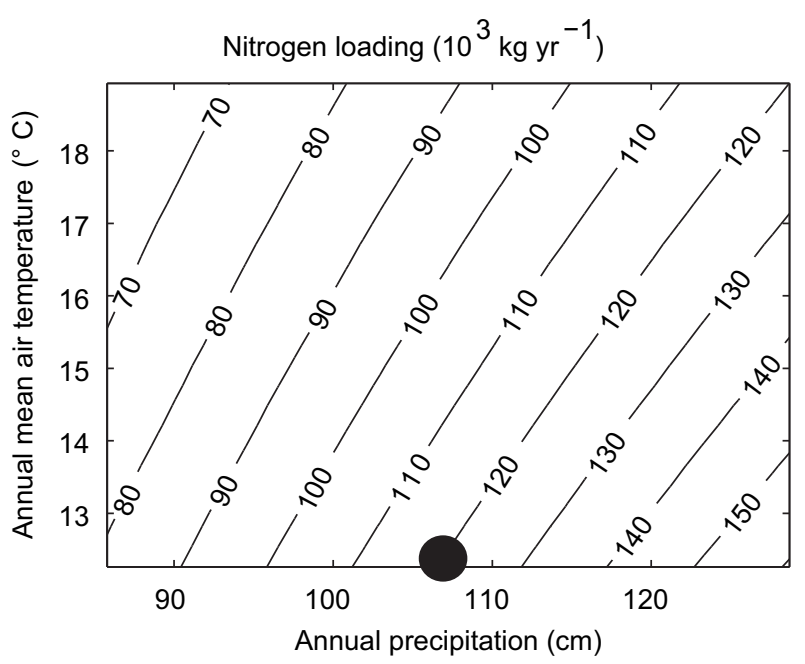

Fig. 9. Simulated annual nitrogen loading in the Western Branch of the Patuxent River, Maryland as a function of annual precipitation and annual mean temperature. The black circle represents recent average conditions. Model output is from Johnson and Kittle (2007).

percentage export of NANI, as Schaefer and Alber (2007) conclude, a warming of $3{ }^{\circ} \mathrm{C}$ would decrease the nitrogen flux down the Susquehanna by about $20 \%$, a trend opposite that predicted by Howarth et al. (2006).

Process-based simulation models of biogeochemical cycling in watersheds offer another approach for assessing the impact of climate change on riverine $\mathrm{N}$ export to coastal waters. However, the current level of uncertainty about the importance of underlying mechanisms that relate nitrogen flux to climatic controls inherently limits the usefulness of such models. Another weakness of processbased models is that they treat organic forms of nitrogen poorly. Though much of the flux of nitrogen in rivers occurs as inorganic nitrogen, increased atmospheric deposition can increase the export of organic nitrogen from forests (Brookshire et al., 2007).

The only process-model-based climate change study of $\mathrm{N}$ export we are aware of in the watersheds of the Chesapeake Bay is that of Johnson and Kittle (2007), who simulated the response of annual nitrogen loading in the Western Branch of the Patuxent River, Maryland to changes in annual mean air temperature and precipitation (Fig. 9). They find that $\mathrm{N}$ export decreases by about 3\% for a temperature increase of $1{ }^{\circ} \mathrm{C}$ and increases by $5 \%$ for a precipitation increase of $5 \%$ (Fig. 9), sensitivities that are much smaller than those found by Howarth et al. (2006) and Schaefer and Alber (2007).

\subsection{Atmospheric deposition of nitrogen}

Atmospheric $\mathrm{N}$ input to the Bay occurs both directly onto the surface of the Bay and onto the landscape with subsequent export to the Bay, and includes both wet deposition and deposition as dry gases and particles. Unfortunately, the dry deposition of many abundant nitrogen pollutant gases (such as $\mathrm{NO}, \mathrm{NO}_{2}, \mathrm{HONO}$, and $\mathrm{NH}_{3}$ ) is not measured in any of the national deposition monitoring programs (NADP, CASTnet, or AIRMon). Total $\mathrm{N}$ deposition is therefore poorly known, with estimates ranging from $14 \%$ to $64 \%$ of the total nitrogen load to the Chesapeake Bay (Castro et al., 2003; Howarth, 2006).

Climate change may alter both the pattern of nitrogen deposition (due to changes in reaction kinetics, precipitation, and wind patterns) and the retention of nitrogen once it is deposited (Section 3.2). Climate change could also influence this partitioning through impacts on growth and productivity of forests, which have been shown to strongly influence the retention of deposited nitrogen (Aber et al., 1998). The impact of these changes may be mediated by forest disturbances, such as gypsy moth outbreaks (Eshleman et al., 2000), which may also be sensitive to climatic variation and change (Gray, 2004).

Climate change also will eventually lead to major changes in the species composition of forests, and these changes are also likely to influence nutrient export. Modeling studies have suggested that habitat for some tree species within the Chesapeake Bay watershed will increase, such as red maple, sweetgum, and loblolly pine, while other currently plentiful species are expected to decline, such as black cherry, American beech, and other oaks (Iverson et al., 2005). Tree species composition, and the resulting litter quality, are important factors in controlling variation in $\mathrm{N}$ cycling in temperate forest soils (e.g., Lovett et al., 2002). Greater abundances of sugar maple and striped maple, for example, were associated with greater net nitrate production in soils relative to coniferous trees (Venterea et al., 2003), making stands dominated by maple species more susceptible to losses of nitrate to surface waters.

\subsection{Freshwater wetlands}

Freshwater wetlands are the interface between human activities in uplands and the streams and rivers of the Chesapeake Bay watershed, and thus have the potential to regulate nutrient inputs to the Bay. Of particular importance for nutrient abatement in the Chesapeake Bay Watershed are riparian ecosystems along loworder streams (Lowrance et al., 1997). Most wetland processes are dependent on catchment-level hydrology (Gitay et al., 2001) and are therefore susceptible to climate change. Potential impacts range from extirpation to enhancement, and include alterations in community structure and changes in ecological function (Burkett and Kusler, 2000). There is evidence that wetlands that depend primarily on precipitation for their water supply may be more vulnerable to climate change than those that depend on regional groundwater systems (Winter, 2000). The number and complexity of factors that influence wetland occurrence and type make it difficult to predict the fate of wetlands directly from knowledge of temperature and precipitation changes alone. Needed are predictions of change in hydrology that will be induced by both climate and land cover change. For example, the hydrologic impacts from changes in rainfall patterns will depend on the amount and location of impervious surfaces in the watershed.

Climate-induced impacts to wetlands will be layered onto an already compromised state of the resource. An assessment of wetland condition in the Upper Juniata River Watershed, PA (Wardrop et al., 2007b) reported that over $68 \%$ of the total wetland area was in medium or low condition, correlated with increasing agriculture and urbanization in the watershed. Two regional assessments of wetland condition indicate that the ability of wetlands in both the Upper Juniata and Nanticoke River watersheds to perform valuable functions, such as removal of inorganic nitrogen and retention of inorganic particulates, is already significantly reduced (Wardrop et al., 2007a), with the majority of wetlands functioning below reference standard levels. These impacts are expressed primarily by modification of supporting hydrology (Brooks et al., 2004). Climate-induced hydrologic regime changes may simply stress these systems further, resulting in their decreased capacity to serve important ecotone functions.

\subsection{Point source pollution}

Growing human populations are very likely to interact with changes in climate to alter discharge from point sources of pollution, such as water treatment plants, industrial facilities, and urban storm 
water systems. Theoretical relationships and studies from other regions suggest the potential for significant impacts, but little work has been done in the Chesapeake Bay Watershed. A screening assessment of the potential impact of climate change on combined sewer overflow (CSO) in the Great Lakes and New England found that CSO systems are designed to function under historical precipitation regimes (U.S. Environmental Protection Agency, 2008b). Design capacity of CSO systems was found to be linearly proportional to anticipated precipitation intensity; as a consequence, significant increases in precipitation intensity (Section 2.3) will likely undermine design assumptions and increase the frequency of overflow events. A similar analysis for publicly-owned treatment works (POTWs) found that the operations of POTWs are sensitive to both the volume of incoming effluent and the hydrologic condition of receiving waters (U.S. Environmental Protection Agency, 2008c). Climate change could therefore have a significant effect on both National Pollutant Discharge Elimination System (NPDES) permitting and POTW financing.

\section{Bay physical response}

\subsection{Circulation}

There are no direct measurements of estuarine circulation in the Chesapeake Bay that document the influence of climate variability. Rather, measurements of temperature and salinity have been used to quantify stratification and infer circulation patterns and rates of mixing. Hagy (2002) analyzed mainstem Bay salinity and temperature data to show that the April-September average stratification in the mid-Bay is strongly and positively correlated to the JanuaryMay average Susquehanna River flow. Given the likely increase in this flow in the future (Section 2.4), it appears that summer-time stratification increases are likely as well. It is unlikely that warming will enhance this stratification significantly because the time scale of climate change is expected to be long enough that the Bay as a whole will warm. Hagy's (2002) diagnostic box modeling of the circulation also showed that the summer-averaged landward advection below the pycnocline into the middle Bay increases with the January-May average Susquehanna River flow.

The only numerical modeling study to consider the impact of climate change on Chesapeake Bay circulation is the recent study by Zhong et al. (2008). This study suggests that the tidal range near Baltimore, Maryland, which is in the upper portion of the Chesapeake Bay, will increase by $15-20 \%$ if sea level increases by $1 \mathrm{~m}$. Zhong et al. (2008) argued that this amplitude increase is caused by friction reduction and the Bay being closer to its resonant period. Increases in tidal range are very likely to be accompanied by increases in mixing and shoreline inundation.

\subsection{Salinity}

Salinity variations throughout the Bay have been shown to be strongly tied to streamflow (e.g., Schubel and Pritchard, 1986). Gibson and Najjar (2000) estimated that a change in annual Susquehanna River flow of $10 \%$ would result in a change in annual mean salinity (of opposite sign) of about 1,4 , and $7 \%$ in the lower, middle, and upper mainstem Bay, respectively. Maximum change in salt concentration is in the central Bay, approximately -0.6 for a $10 \%$ flow increase. With projected annual flow changes by the end of the $21^{\text {st }}$ century of -40 to $+30 \%$ (Section 2.4 ), annual mean salinity in the central Bay could change by as much as 2 in either direction.

Salinity variability is very likely to be affected by climate change. Given the projected increases in January-May flow of the Susquehanna River (Section 2.4), we can expect a decrease in mean salinity during the winter and spring; summer and fall projections are much more uncertain. Saltwater intrusion events with durations greater than 1 month are likely to increase because of the projected increases in drought frequency (Section 2.4).

Only one study has attempted to quantify salinity variations due to sea-level rise in the Chesapeake Bay. After accounting for streamflow variations, Hilton et al. (2008) found significant trends in about half of the volume of the mainstem Chesapeake Bay between 1949 and 2006, during which average sea level in the Bay rose by about $0.2 \mathrm{~m}$. The mean salinity change in these regions was about 0.8 , at least half of which could be explained by sea-level rise, according to hydrodynamic model simulations. Given a salinity sensitivity to sea level of about $0.4 \div 0.2 \mathrm{~m}=2 \mathrm{~m}^{-1}$, a sea-level rise of 0.7 to $1.6 \mathrm{~m}$ by 2100 (Section 2.5 ) would increase salinity by 1.4 to 3.2 .

\subsection{Suspended sediment}

Excess sediment contributes substantially to the Bay's poor water quality (Langland et al., 2003), the majority of this sediment is non-volatile (Cerco et al., 2004), and this non-volatile component is mainly delivered by rivers (Smith et al., 2003). In 2003, The Chesapeake Bay Program (CBP), proposed to reduce land-based sediment loading $18 \%$ by 2010 in order to achieve the water clarity needed for underwater grasses to survive (Chesapeake Bay Program, 2003). A least squares fit to the data in Fig. 7 yields a sediment load of $87 \mathrm{~kg} \mathrm{~s}^{-1}$ for the mean streamflow of $1890 \mathrm{~m}^{3} \mathrm{~s}^{-1}$ during 1990-2004. Using projected flow changes by the end of the $21^{\text {st }}$ century of -40 to $+30 \%$ (Section 2.4 ), we estimate that the mean sediment load could increase to $200 \mathrm{~kg} \mathrm{~s}^{-1}$, more than a doubling, or decrease to $28 \mathrm{~kg} \mathrm{~s}^{-1}$, less than a third of the current load. Thus climate change has the potential to either undo efforts to meet water clarity goals or make it much easier to reach them. As noted above, more intense precipitation in fewer events will probably increase sediment loading, but the sensitivity is unknown.

In addition to natural and anthropogenic processes in watersheds that influence suspended sediment concentrations in rivers, estuarine suspended sediment is controlled by a variety of processes: the amount of streamflow entering the estuary, shoreline erosion, in situ biological production and decomposition, the re-suspension of particulate matter through currents (driven by winds, tides and buoyancy forces), the redistribution by advection and mixing within the estuary, and the rate of sedimentation. Many of these controls are also sensitive to climate, but quantitative relationships that link climate change to changes in sediment fluxes are lacking.

\section{Estuarine biogeochemistry}

\subsection{Nutrient cycling and plankton productivity}

While dominated by diatoms throughout the year (Adolf et al., 2006), phytoplankton production and species composition in the Chesapeake Bay generally follow predictable seasonal patterns dictated primarily by streamflow, light, and temperature (Malone et al., 1996; Marshall and Nesius, 1996). Meteorology, through river discharge, governs spring bloom timing and extent (Harding, 1994). During the relatively low-light, cold, and turbulent winter/earlyspring period, centric diatoms dominate the flora (Sellner, 1987). As nutrients delivered by the spring freshet are exhausted from the surface waters, a substantial fraction of the spring diatom bloom sinks (mostly as intact cells) through the pycnocline. Thereafter, surface summer productivity is supported by nutrient supply from below the pycnocline via wind-induced destratification and pycnocline tilting (Malone, 1992). During the warm stable summer months, the algal community shifts to a mixture of picoplankton, small centric diatoms, and flagellates (Malone et al., 1986). 
Aperiodic dinoflagellate blooms are also frequent and some taxa, such as Pfiesteria spp. and Karlodinium veneficum (Place et al., 2008), may exert toxic or other harmful effects. At this time, primary productivity (most of which is due to rapid nutrient recycling), microzooplankton grazing, zooplankton production, and fish production (Section 7.3) are high.

Climate change has the potential to alter Bay phytoplankton dynamics through changes in precipitation and the intensity and frequency of storms. The projected winter-spring precipitation increases for the Bay watershed (Fig. 4, Section 2.3) will likely increase nutrient loading during these seasons, leading to higher planktonic production. Higher temperatures will likely result in an earlier spring bloom, which could cause trophic uncoupling or change the spatial distributions of particular taxa (e.g., Edwards and Richardson, 2004). The summer period, depicted as more drought-likely (Section 2.4), could be typified by sporadic, high intensity storms and discharge events. If storms are overland, resulting discharge would lead to increases in short-term stratification and increased preponderance of algal blooms (Mulholland et al., 2009), including some of the problematic taxa identified above. Should the intense storms pass over the Bay and tributaries, mixing of the water column would very likely occur, probably with increased discharge; this would yield optimal conditions for diatom growth, similar to the fall bloom in the mesohaline Bay (Sellner, 1987). Climate change might therefore result in an annual phytoplankton cycle with a larger-than-average spring diatom bloom, followed by small cells during the summer drought, interspersed with aperiodic dinoflagellate blooms or diatom maxima after storms pass. Species diversity already appears to have increased over the last 20 years (Marshall et al., 2004) as has chlorophyll $a$ (Kemp et al., 2005), effects largely attributed to eutrophication. The continued interactive effects of climate change and eutrophication on these already documented changes are likely to be profound in the Chesapeake Bay system.

\section{2. $\mathrm{CO}_{2}$ and temperature effects on plankton}

$\mathrm{CO}_{2}$ is the preferred form of carbon for the principle carbonfixing enzyme, ribulose-1,5-bisphosphate carboxylase-oxygenase (Rubisco); however, most of the dissolved inorganic carbon in seawater is bicarbonate ion $\left(\mathrm{HCO}_{3}^{-}\right)$. As a consequence, most cells have various carbon concentrating mechanisms (CCMs) in order to concentrate $\mathrm{CO}_{2}$ near active Rubisco sites. Species without CCMs are very likely to benefit directly from increases in $\mathrm{CO}_{2}$ (Section 2.1, Fig. 2b). Further, there are different forms of Rubisco with different affinities for $\mathrm{CO}_{2}$. Some of the bloom-forming microalgae are dinoflagellates that appear to have a form of Rubisco that has a low affinity for $\mathrm{CO}_{2}$ compared with the Rubisco found in most other microalgae (e.g., Ratti et al., 2007). $\mathrm{CO}_{2}$ increases might alleviate carbon limitation of Rubisco and allow higher growth rates of these dinoflagellates, thereby increasing the number of harmful algal blooms throughout the system. While high $\mathrm{CO}_{2}$ might result in increased $C$ productivity, enhanced carbon fixation does not result in enhanced nutrient drawdown or increases in the $C$ content of cells (Riebesell et al., 2007). Rather, enhanced carbon fixation, at least in some cases, results in release of dissolved organic carbon (DOC) that could fuel microbial heterotrophs and change net system metabolism (Riebesell et al., 2007).

$\mathrm{CO}_{2}$ has been shown to stimulate diatom growth relative to that of prymnesiophytes in incubations of natural communities (Tortell et al., 2002), and it has stimulated dinoflagellate (Rost et al., 2006), coccolithophorid (Riebesell et al., 2007), and cyanobacterial growth in cultures. Synechococcus growth as well as growth of the raphidophyte Heterosigma akashiwo were stimulated under both high $\mathrm{CO}_{2}$ and high temperature scenarios (Fu et al., 2008a,b), whereas the common late spring bloom-former Prorocentrum. minimum was less affected (Fu et al., 2008b).

Temperature increases are very likely to affect the metabolic status of the Chesapeake Bay. In a synthesis of microbial rate measurements in the Chesapeake Bay, Lomas et al. (2002) found that planktonic respiration increases with temperature more rapidly than photosynthesis. Their results suggest that the Bay might become net heterotrophic on an annual time scale, reversing its current net autotrophic status (Smith and Kemp, 1995). The combined impact of excess DOC release by phytoplankton due to carbon overproduction and increasing temperature are very likely to have significant effects on the microbial community.

\subsection{Harmful algal blooms and pathogens}

Peperzak (2003) conducted several experiments with brackish bloom-forming and non-bloom forming taxa under simulated stratified conditions and a $4{ }^{\circ} \mathrm{C}$ temperature increase. Skeletonema costatum, a common winter-spring taxon in the Bay, was not perturbed by the shift to stratified conditions. However, P. minimum, the spring co-dominant in the Chesapeake (and occasional toxin producer), and two raphidophytes (Heterosigma spp.) found in midAtlantic coastal bays, were stimulated by the increased stratification and temperature.

Shifts in algal taxonomic composition from flow-induced stratification pose potential problems both in terms of altered food web structure and toxicity to trophic groups. Several taxa can reduce zooplankton grazing and fecundity due to poor food quality (e.g., Harvey et al., 1989) or the production of toxins or grazingdeterrent compounds (e.g., Adolf et al., 2007). Very high cell abundances can also reduce grazing pressure from co-occurring zooplankton populations (e.g., Sellner and Olson, 1985). Pelagic bacterial production may increase as well due to surface-mixedlayer lysis of dinoflagellates (Sellner et al., 1992), favoring heterotrophic flagellates rather than copepods. The net result is an increase in the importance of the microbial food web rather than the classical food chain that supports fish production.

Additional impacts of an altered climate, specifically prolonged droughts (Hayhoe et al., 2007), will result in increased oceanic intrusion into the Bay, introducing coastal populations of phytoplankton, including several harmful taxa. This occurred during the spring and summer of 2002 following drought conditions in 19992002: coastal populations of Dinophysis acuminata were delivered to the lower Potomac River estuary (Marshall et al., 2004), resulting in fears for okadaic acid intoxication and diarhettic shellfish poisoning for the oyster-consuming public. During summer 2007, prolonged drought followed by storm events that resulted in overland run-off is thought to have triggered an extensive bloom of Cochlodinium polykrikoides in the lower Chesapeake Bay (Mulholland et al., 2009). Alexandrium monolitum, common in the Gulf of Mexico but previously undetected in the Chesapeake Bay watershed, appeared to enter the Chesapeake Bay and co-occurred with C. polykrikoides during the latter half of this bloom (Marshall and Egerton, 2009).

The leafy chlorophyte Enteromorpha, a macroalga, is stimulated by elevated water temperatures (Lotze and Worm, 2002) and along with a similar taxon, Ulva, is characteristic of eutrophic estuaries including the Chesapeake and its tributaries. It is conceivable that warmer winters and springs might favor earlier growth of these two macroalgae and contribute to fouling of shorelines and submerged vegetation, clogging of commercial fish nets, and hypoxic conditions in sheltered bays. Further, the decay of these blooms has been associated with the onset of other harmful algal blooms in other areas, such as Aureococcus anophagefferens (Kana et al., 2004).

Harmful bacteria will also respond to temperature changes. Some true heterotrophic bacteria, like the Vibrio species, are associated 
with serious illnesses, such as gangrene and sepsis. Pathogenic species, such as Vibrio vulnificus and Vibrio cholerae, have been identified in Chesapeake Bay waters (summarized in Rose et al., 2000). Vibrio cholerae and Vibrio. parahaemolyticus appear to be associated with elevated sea surface temperatures (Colwell, 1996; McLaughlin et al., 2005). Further, growth of a free-living strain of this bacterium has been shown to be stimulated by a coastal dinoflagellate bloom off of California (Mouriño-Pérez et al., 2003), reaching levels three orders of magnitude higher than the known minimum infectious dose. Therefore, climate-induced increases in harmful algal blooms may increase threats to human health either directly or by fueling pathogen growth with bloom-derived organic matter.

Shellfish ingestion and concentration of pathogenic bacteria can also lead to outbreaks of gastroenteritis, and with $V$. vulnificus, death in some human consumers (Rose et al., 2000 and references therein). Increasing temperatures in the Chesapeake Bay would favor these bacteria (as noted above), increasing the threat of this disease in the basin.

\subsection{Dissolved oxygen}

Dissolved oxygen levels have become a central indicator of the overall health of the Chesapeake Bay. Hypoxia is caused by the combination of the sinking of the spring phytoplankton bloom, which fuels bottom respiration, and density stratification, which inhibits mixing that would otherwise replenish the deeper waters with oxygen (Malone, 1992). The significant trend of increasing intensity, duration, and extent of hypoxic conditions since 1950 is related to increased nutrient loading from human activities in the watershed (Hagy et al., 2004).

Climate influences the spatial and temporal distribution of hypoxic conditions. Hagy et al. (2004) found January-May average flow of the Susquehanna River to be a good predictor of the subsequent summertime volumes of low-oxygen water. Their functional fits to the data suggest that a $10 \%$ flow increase will increase the volume of anoxic water $\left(<0.2 \mathrm{mg} \mathrm{l}^{-1}\right)$ by $10 \%$, severely hypoxic water $\left(<1.0 \mathrm{mgl}^{-1}\right)$ by $6 \%$, and mildly hypoxic water $\left(<2.0 \mathrm{mg}^{-1}\right)$ by $3 \%$. Thus, if January-May Susquehanna River flow increases throughout the $21^{\text {st }}$ century, as expected (Section 2.4), then it is very likely that summertime oxygen levels will decline.

Lower $\mathrm{O}_{2}$ solubility associated with warming would contribute to further reductions in bottom water $\mathrm{O}_{2}$ concentrations. The sensitivity of the oxygen saturation concentration to temperature at the temperature of sub-pycnocline waters in July $\left(\sim 20^{\circ} \mathrm{C}\right)$ is -0.16 $\mathrm{mg} \mathrm{l}^{-1}{ }^{\circ} \mathrm{C}^{-1}$. The difference in oxygen concentration between severely hypoxic and anoxic waters as defined above is $0.8 \mathrm{mgl}^{-1}$. Thus a warming of even $5{ }^{\circ} \mathrm{C}$ could make waters that are currently severely hypoxic turn anoxic solely due to solubility effects.

Higher temperatures would also tend to accelerate rates of nutrient recycling, further stimulating phytoplankton production and potentially deposition (e.g., Kemp et al., 2005). This, coupled with the $\mathrm{CO}_{2}$-stimulated phytoplankton production and the suggested shift towards greater heterotrophy with warming (Section 5.2 ), would tend to drive oxygen concentrations even lower. Simulation modeling studies for the northern Gulf of Mexico support these hypothesized responses of bottom water hypoxia to climate change scenarios (Justić et al., 2003).

\section{Vascular plants}

\subsection{Submerged aquatic vegetation}

Availability of light is a primary factor regulating submerged aquatic vegetation (SAV) abundance and spatial distribution in the Chesapeake Bay (Kemp et al., 2004, 2005). A major decline in the
Bay's SAV abundance, which began in the mid-1960s (Orth and Moore, 1983), was very likely due to widespread decreases in light availability that resulted from increases in suspended sediments and nutrient-stimulated growth of planktonic and epiphytic algae throughout the estuary (e.g., Moore and Wetzel, 2000). The light sensitivity of SAV may be particularly problematic in the context of climate change given the possibility of significant increases in sediment loading resulting from greater and more episodic precipitation (Sections 2.3 and 3.1).

SAV species exhibit widely varying sensitivity to temperature, with optimal growth ranges of $22-25^{\circ} \mathrm{C}$ for eelgrass (Bintz et al., 2003) and $30-35{ }^{\circ} \mathrm{C}$ for various freshwater plants growing in brackish habitats (Santamaría and van Vierssen, 1997). It is anticipated that higher temperatures will favor some species over others (Ehlers et al., 2008). However, a massive summer 2005 die-off in Chesapeake Bay eelgrass, which was triggered by an extended hot period with daily peak water temperatures exceeding $33-35^{\circ} \mathrm{C}$, underscores the fact that the Bay is near the southern geographic limit for this species (Moore and Jarvis, 2008; Orth et al., review). With heat waves projected to increase in the Mid-Atlantic region (Section 2.2), we can expect such die-offs to become more frequent in the future. It appears that high temperatures and low water column mixing may contribute to internal oxygen deficiency, degradation of meristematic tissue, and mortality for eelgrass and other SAV (Greve et al., 2003). Higher temperatures may also favor growth of epiphytic algae to further reduce light available to SAV (Bintz et al., 2003; Short and Neckles, 1999).

Inter-annual variations in SAV distribution and abundance in the Choptank River estuary and other mesohaline Bay areas appear to correspond to fluctuations in freshwater flow. In general, decreased river flow results in reduced nutrient and sediment loading, clearer estuarine water, and higher plant growth (Stevenson et al., 1993). For example, a resurgence of the euryhaline widgeon grass (Ruppia maritima) occurred in the lower Choptank estuary after three successive drought periods (2-4 years each) during the 1980s and early 1990s (Kemp et al., 2005; Orth et al., review). This pioneer SAV species, which is sensitive to variations in light availability and reproduces annually from an established seed bank, has expanded in this region to form generally stable monospecific stands (Orth et al., review). These $R$. maritima beds, however, exhibit year-to-year fluctuations in abundance that correlate well with spring river flow and summer water clarity (Fig. 10). In previous decades, this region was also populated by a more diverse community of SAV comprised mostly of freshwater species that have varying tolerance for brackish conditions (e.g., Moore et al., 2000). For many of these plant species, increased salinity associated with reductions in river flow can produce osmotic stress that precludes their growth and survival, despite improved water clarity (Stevenson et al., 1993). Thus, climateinduced variations in freshwater flow would tend to affect SAV communities in middle regions of the Bay and its tributaries in complex ways, with abundance of salt-tolerant species expanding but species diversity declining under reduced flow conditions.

In addition to temperature, salinity, and light, SAV is sensitive to $\mathrm{pH}$ and $\mathrm{CO}_{2}$ concentration. Although eelgrass was shown to increase productivity under elevated $\mathrm{CO}_{2}$ levels, with a $25 \%$ increase in biomass under a doubling of $\mathrm{CO}_{2}$, there was no response under light-limiting conditions (Palacios and Zimmerman, 2007). Earlier studies showed that responses vary substantially with duration of exposure to $\mathrm{CO}_{2}$ levels (e.g., Thom, 1996). The more recent results, however, suggest that $\mathrm{CO}_{2}$ increases could aid SAV restoration efforts, but only if measures are also taken to maintain sufficient water clarity. In addition, SAV species vary widely in their affinities for both carbon dioxide and bicarbonate (e.g., Beer and Koch, 1996), suggesting that higher $\mathrm{CO}_{2}$ levels may contribute to alteration in species composition. 

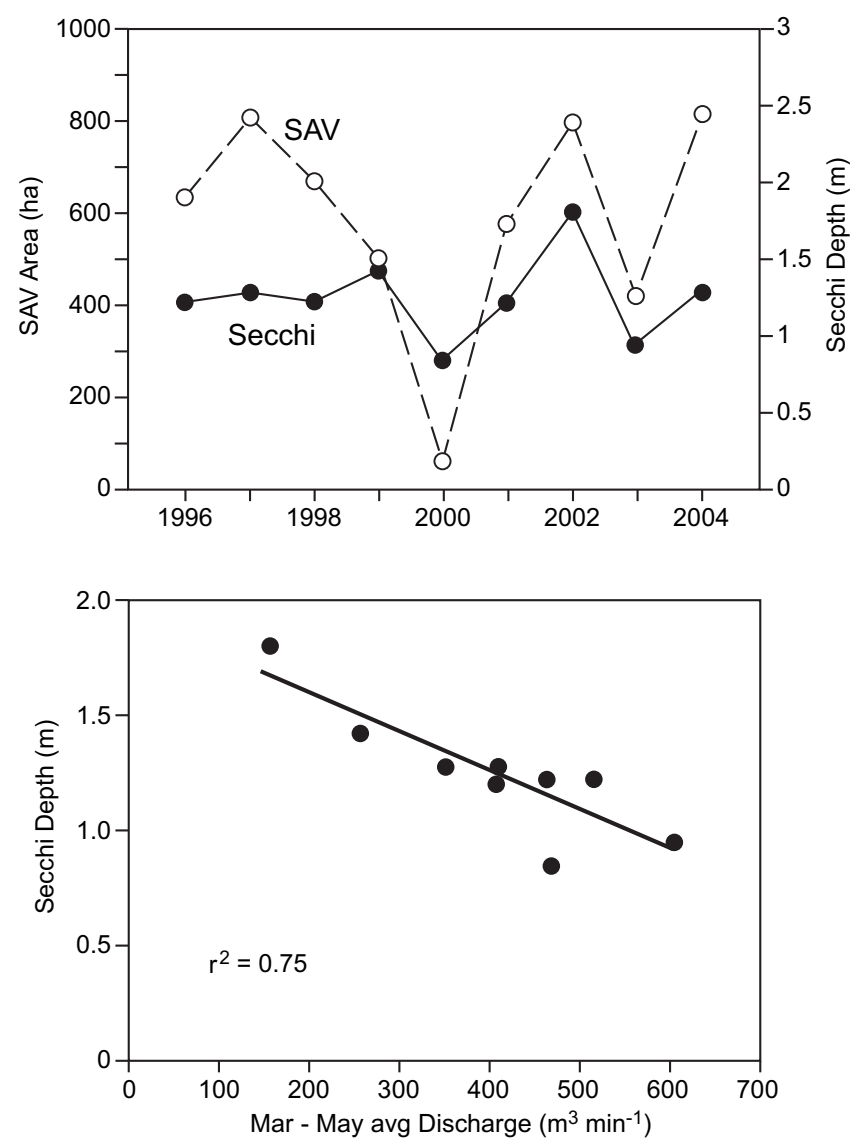

Fig. 10. Comparison of Choptank River flow and Secchi depth and areal cover for submersed aquatic vegetation (SAV, primarily Ruppia maritima) in the lower Choptank estuary over a recent 9-year period. SAV areal cover (aerial photos from single last summer flight, generally July or August) and Secchi depth (Station EE2.1, April-October means) data are from chesapeakebay.net and Choptank river flow data are from www.waterdata.usgs. gov. Variation in SAV cover is significantly $(p<0.03)$ related to Secchi depth as follows: SAV $=633$ Secchi $-203\left(r^{2}=0.50\right)$, and variation in Secchi depth is significantly $(p<0.002)$ related to river flow as follows: Secchi $=1.95-0.003$ Flow $\left(r^{2}=0.75\right)$.

\subsection{Estuarine wetlands}

Inundation by rising sea levels is one of the most direct threats faced by coastal and estuarine wetlands in the Chesapeake Bay region. The amount of land inundated by a given sea-level rise is a complex function of elevation, shoreline geology, land use, land cover, wetland ecology, and the rate of sea-level rise. Two studies have estimated inundation for the Chesapeake Bay shoreline, and both have relied on elevation alone. Titus and Richman (2001), using Digital Elevation Models (DEMs) and shoreline data, estimated that about $2500 \mathrm{~km}^{2}$ of land is below the $1.5-\mathrm{m}$ elevation contour in Virginia and Maryland (essentially the shores of Chesapeake Bay). Wu et al. (2009) used DEMs with finer (30-m) horizontal resolution to estimate that $1700 \mathrm{~km}^{2}$ of land in Virginia and Maryland lies below the $0.7-\mathrm{m}$ contour, about half of which is wetlands.

The current forecasts for the rates of sea-level rise in the Chesapeake Bay are significantly greater than rates experienced for the last several centuries (Section 2.5). At present it is not clear how much of the existing wetland complement in the Bay region will be able to either accrete vertically or migrate horizontally fast enough to keep pace with the accelerated rate of change (e.g., Kearney et al., 1994). Extensive wetlands along the mainstem of the Bay, such as the Blackwater Wildlife Refuge in Maryland and the Guinea Marshes in Virginia, are already showing decreased areas of vegetative cover as a result of inundation and erosion. Extensive oxbow wetlands at the headwaters of the Bay's tidal tributaries are also undergoing changes in vegetative community composition that seem related to increased inundation frequency, a sign that the wetland is not keeping pace with rising sea level (Perry and Hershner, 1999).

Wetlands will also respond to elevated levels of atmospheric $\mathrm{CO}_{2}$, increasing temperatures, and changing salinity patterns. A Scirpus olneyi wetland sedge community of the Rhode River (a subestuary of the Chesapeake Bay) that was exposed to an approximate doubling of atmospheric $\mathrm{CO}_{2}$ over a 17-year period revealed enhanced shoot density, shoot biomass, and rates of net $\mathrm{CO}_{2}$ uptake compared to ambient exposures (Rasse et al., 2005). In contrast, Spartina patens showed no significant response to $\mathrm{CO}_{2}$ (Erickson et al., 2007). Rasse et al. (2005) also clearly documented salinity stress on S. olneyi, with significant anti-correlations at the interannual time scale between salinity and the three growth measures referred to above. Elevated $\mathrm{CO}_{2}$-stimulation of plant growth has important implications for brackish marshes, many of which are dominated by C3 plant species such as S. olneyi. Indeed, recent results from a Rhode River marsh (Langley et al., 2009) show that elevated $\mathrm{CO}_{2}$ increases root biomass, which in turn raises elevation of the tidal marsh soil. The increase in elevation was $3.9 \mathrm{~mm} \mathrm{yr}^{-1}$, similar to the current average rate of relative sea-level rise in the Chesapeake Bay (Section 2.5). Thus, elevated $\mathrm{CO}_{2}$ may stimulate marsh accretion and ameliorate marsh losses projected from accelerated sea-level rise. The combination of temperature increases and elevated $\mathrm{CO}_{2}$ concentrations may produce different effects on marshes than elevated $\mathrm{CO}_{2}$ alone, but we presently know little about these interactions.

The impact of rising sea level is compounded by on-going landuse and land-cover change and associated shoreline hardening. Increased shoreline hardening has limited the ability of marshes to migrate in response to sea-level rise. Land-use projections for some portions of the Chesapeake Bay shoreline exist (e.g., Dingerson, 2005), but we know of none that simultaneously link to sea-level rise and shoreline condition. However, it seems likely that the threat of increased erosion and damage to property from higher sea level, more intense storms, and a greater tidal range (Section 2.5) will be an increase in shoreline hardening and stabilization structures. These structures can reduce the sandy sediment source that is critical to healthy shoreline habitat (National Research Council, 2007).

Inundation of coastal wetlands by rising sea levels may stress the systems in ways that enhance the potential for invasion of less desirable species, such as Phragmites australis (one of six species identified as causing, or having the potential to cause, significant degradation of the aquatic ecosystem of the Bay) (U.S. Environmental Protection Agency, 2008a). Reported impacts include significant loss of plant diversity (e.g., Meyerson et al., 2002), changes in marsh hydrology with the development of Phragmites stands (see Marks et al., 1994), and a reduction in insect, avian, and other animal assemblages (Chambers et al., 1999). Shifts within native plant communities are also probable, although difficult to predict with current experimental data (Dukes, 2007). Additionally, for many marsh systems to persist, a continued input of suspended sediment from inflowing streams and rivers is required to allow for soil accretion. Climate change will alter the timing and overall delivery of sediment from upstream sources, but these consequences remain uncertain (Section 3.1).

\section{Fish and shellfish}

Species in the Chesapeake Bay food web vary in the relative importance and specific optimal values of temperature, photoperiod, salinity, and prey abundances as controls or cues for growth, reproduction, and migration. As a result, climate change that affects these variables, or that decouples the current relationships among 
them, may differentially affect species within the food web. The likely results will include direct effects on the timing and magnitude of abundances of individual species as well as changes in the match between seasonal abundances of some predators and prey.

\subsection{Temperature impacts on fish and shellfish}

As warming progresses, it should differentially affect the warmand cold-temperate fish and shellfish that utilize the Bay either year round or as seasonal feeding, nursery, and wintering habitat. Species with more southerly distributions and temperature tolerances will likely benefit (Austin, 2002; Wood, 2000), but some coldtemperate species near the upper limits of thermal tolerances may reduce use of the Chesapeake Bay and have lower production within Bay waters. Thermal tolerances of embryos and early larval stages may be particularly important in determining shifts in species distributions (Rombough, 1997). Developing embryos of fishes are generally less able to acclimate and compensate for changes in temperature and tend to have narrower temperature tolerances than other life stages.

Northward range expansions and extended seasonal use of Bay waters by warm-water species may enhance some fisheries. Shrimps of the genus Farfantepenaeus, which now support important fisheries in North Carolina (Hettler, 1992), could increase and support viable fisheries in the Chesapeake Bay and elsewhere in the midAtlantic Bight. Species with southerly distributions that already occur in Chesapeake Bay and Virginia coastal waters and would be expected to increase in abundance or seasonal duration within Bay waters include southern flounder Paralichthys lethostigma, cobia Rachycentron canadam, spadefish Chaetodipterus faber, Spanish mackerel Scomberomorus maculatus, mullet Mugil curema, tarpon Megalops atlanticus, and pinfish Lagodon rhomboides (Murdy et al., 1997), as well as sub-tropical drums (Sciaenidae) such as black drum Pogonias cromis, red drum Sciaenops ocellatus, weakfish Cynoscion regalis, spotted sea trout $C$. nebulosus, spot Leiostomus xanthurus, and Northern Menticirrhus saxatilis and Southern kingfish M. americanus.

Higher water temperatures during winter, in particular, may have positive effects on some species. Overwintering mortality can be an important factor contributing to year-class strength (Conover and Present, 1990). Higher winter temperatures result in higher juvenile overwintering survival and stronger year classes of Atlantic croaker Micropogonias undulatus in the mid-Atlantic (Hare and Able, 2007), and increase overwintering survival of both juvenile (Bauer, 2006) and adult (Rome et al., 2005) blue crab in the Chesapeake Bay. Milder winters should also lead to longer growth seasons for species resident to the Chesapeake Bay such as oysters, blue crab, eels, white perch Morone americana, and the resident portion of the striped bass Morone saxatilis population (Hurst and Conover, 1998; Johnson and Evans, 1996). Longer growth seasons could lead to increased productivity and yield of commercial fisheries by increasing annual growth rates and increasing the size or decreasing the age of reproduction (Puckett et al., 2008). This assumes that warmer winters coincide with sufficient prey and that warming in other seasons does not offset longer growth seasons due to increased incidence of disease or hypoxia (Sections 5.4 and 7.4).

The degree to which the Chesapeake Bay freezes over is already much reduced in comparison to 50 years ago (Boesch, 2008). Lack of surface freezing in shoreline habitats could increase opportunities for oysters and other intertidal species to colonize shorelines and form emergent reefs. Shoreline and emergent reefs would increase access to new habitat for restoration and aquaculture.

In contrast to the generally positive effects predicted for southerly species, higher temperatures may decrease the areal extent of bioenergetically favorable Bay habitats for cold-temperate species both directly and in combination with low oxygen (Sections
5.4 and 7.4). Species that are at their southernmost range in the mid-Atlantic region will be eliminated from the Chesapeake Bay if water temperatures reach levels that are lethal or that inhibit successful reproduction. For example, the commercially important soft clam Mya arenaria in the Chesapeake Bay is near its southern distribution limit and may be extirpated if temperatures approach and remain near $\sim 32{ }^{\circ} \mathrm{C}$ (Kennedy and Mihursky, 1971). Temperate fish species such as yellow perch Perca fulvescens, white perch, striped bass, black sea bass Centropomis striata, tautog Tautoga onitis, summer Paralichthys dentatus and winter flounders Pleuronectes americanus, silver hake Merluccius bilinearis, and scup Stenotomus chrysops will likely be stressed by Chesapeake warming during summer.

Warmer and shorter winter seasons may, nevertheless, allow for earlier spring immigration and later fall emigration of some coastal species, including cool-temperate fishes (e.g., see Frank et al., 1990 for the St. Lawrence region). Assuming continued use of Bay waters, striped bass, shads (Alosa sp.) and other fish that migrate into the Chesapeake for spring spawning will likely arrive earlier. American shad now migrate up the Columbia River (where they have been introduced) 38 days earlier than during the 1950s as water temperatures have increased as a result of reductions in spring flow by the Bonneville Dam (Quinn and Adams, 1996).

Physical and ecological factors other than temperature may preclude a smooth transition to a balanced ecosystem dominated by warm-water fishery species. Oligohaline-upper mesohaline species (such as the bivalves Mytilopsis leucophaeata or Ischadium recurvum) that live only in estuaries may spread northward slowly if they cannot tolerate the marine conditions that occur between estuaries. Increasing temperatures, along with other climate-related changes in the Bay environment, may also facilitate the successful northward expansion of non-native species (Stachowicz et al., 2002) and pathogens (Cook et al., 1998). As recently as 1987, the Chesapeake Bay was the largest oyster producer on the Atlantic and Gulf of Mexico coasts (Haven, 1987). While overfishing has historically played an important role in the demise of this fishery, two oyster pathogens, Perkinsus marinus (Dermo) and Haplosporidium nelsoni (MSX), have contributed to the long-term decline and have hindered the population's recovery despite considerable restoration efforts (Andrews, 1996). Warmer winters appear to have already increased these diseases in oyster populations in Atlantic Coast estuaries (e.g., Cook et al., 1998). The strong temperature dependence of Dermo, in particular, suggests that the Chesapeake region could experience increased oyster parasite stress in subtidal oysters as local water temperatures increase.

Some fish parasites might also benefit from warmer climes. Weisberg et al. (1986) have documented increases in the intermediate host Limnodrilus sp. for the fish redworm Eustrongylides sp. (pathogenic to avian definitive hosts) in warming eutrophic waters of the Bay; the fish infected include yellow perch (Muzzall, 1999), which is common to the Bay. Warmer shelf waters might also lead to earlier arrivals and later departures of pelagic fishes (e.g., Frank et al., 1990), favoring transmission of pelagic oriented parasites, as has been suggested for the St. Lawrence River and Japan, increasing human illness from pathogen transfer via undercooked fish (Hubert et al., 1989).

Winter survival of potential pathogens is also hinted at in recent observations in upper river basins. In the last four years, winter water temperatures have been substantially higher in the upper Shenandoah River area than the past, and each spring thereafter, major smallmouth bass mortalities have been observed. Winter pathogen survival has been suggested as one explanation for these recurring events (Chesapeake Bay Foundation, 2007) and, if this hypothesis is correct, overwintering success and subsequent spring illnesses or mortalities may become increasingly common as regional water temperatures rise. 
Finally, warming may also influence pollutant impacts. Higher temperature-induced-mercury methylation (Booth and Zeller, 2005) has, for example, been suggested as a possible mechanism to increase mercury uptake in fish and increase potential fetal impacts (Bambrick and Kjellstrom, 2004; from McMichael et al., 2006); fish tissue mercury concentrations are already a public health concern in Chesapeake jurisdictions.

\subsection{Salinity impacts on fish and shellfish}

The most pronounced effects of altered salinity distributions (Section 4.2) on fishery species will likely result from changes in the distribution and abundance of predators, prey, and pathogens. The two examples considered here, the eastern oyster and gelatinous zooplankton, illustrate how these factors may play out.

Salinity affects the eastern oyster in at least three ways. First, the oyster has a physiological salinity range of 5 to 35 . Second, mortality from Perkinsus and Haplosporidium infections is greatest at salinities above about 12 (Haven, 1987). Third, spatfall success (recruitment) in the Bay oyster population has been shown to be positively affected by higher salinity (e.g., Kimmel and Newell, 2007). The net effect of these three factors in the face of salinity increases, which will very likely occur if precipitation remains unchanged, may depend on whether the combination of favorable conditions for recruitment and high parasite stress affect selection for disease tolerance in infected oysters.

The second example involves the two dominant gelatinous zooplankton species within the Bay, the ctenophore Mnemiopsis leidyi and its scyphomedusan predator Chrysaora quinquecirrha (the sea nettle) (Purcell and Arai, 2000). Both of these species feed directly on fish eggs and larvae (e.g., Cowan and Houde, 1993; Monteleone and Duguay, 2003) as well as on zooplankton that are important prey for adult forage fish and other fish species in early life stages (e.g., Burrell and Van Engel, 1976; Purcell, 1992). Mnemiopsis leidyi has a greater ability to deplete its prey than does C. quinquecirrha, and also feeds on oyster larvae. Interannual variability in salinity and flow strongly affect the timing of peak sea nettle abundances, with abundances peaking earlier in years of above-average salinity (Breitburg and Fulford, 2006). Consequently, climate change may ultimately influence the timing and magnitude of direct effects of sea nettle consumption of icthyoplankton and other zooplankton, as well as indirect effects mediated through the control sea nettles exert over their ctenophore, M. leidyi, prey.

\subsection{Prey production impacts on fish and shellfish}

The predicted combination of increases in both temperatures and winter flows could decouple the combination of environmental factors historically associated with favoring particular Bay species and high total fisheries production of Chesapeake Bay waters. Analysis of Chesapeake assemblages show that low temperatures and high flows in winter are associated with high summer-fall abundances of juvenile Atlantic silversides Menidia menidia (an important forage fish), striped bass, white perch, and Atlantic needlefish Strongylura marina (Kaushal et al., in press). Species associated with the converse, low winter flows and high winter temperatures, include bluefish Pomatomus saltatrix, spot, bay anchovy Anchoa mitchilli, and northern puffer Sphoeroides maculatus. Shifts between these two juvenile assemblages occurred between average winters that differed by $\sim 1{ }^{\circ} \mathrm{C}$-well within the range of warming expected in the next 50 years (Section 2.2) -but effects of higher temperatures combined with higher flows is difficult to predict.

Similarly, the predicted earlier and stronger spring freshet (Section 2.4) on Chesapeake Bay fisheries is not clear. Fisheries production in the Bay, as in most mid-latitude temperate systems, is strongly tied to the progression of annual production that is initiated by high early-spring streamflow (Section 5.1) (e.g., Silvert, 1993). The timing and magnitude of the spring zooplankton bloom that provides food for young-of-the-year of spring spawning fishes and forage fish species that actively feed in the Bay in early spring is influenced by winter weather and spring streamflow (Kimmel et al., 2006). A change in the timing of the spring freshet could alter fishery production, but specific effects are better known for reduced and later freshets (Wood and Austin, 2009) than for changes in the direction predicted.

Warmer summers may also affect predation mortality of early life stages of summer breeding fish and shellfish. Lethal temperature for the lobate ctenophore, $M$. leidyi, collected from the Chesapeake Bay is approximately $30^{\circ} \mathrm{C}$ in laboratory experiments (Breitburg, 2002). Both latitudinal variation and shifts in the timing of peak ctenophore abundances with increasing temperatures in Narragannsett Bay (Sullivan et al., 2001) indicate the potential for temperature increases to alter the temporal overlap between these predators and the early life stages of fish and shellfish on which they prey.

\subsection{Dissolved oxygen impacts on fish and shellfish}

Low dissolved oxygen affects growth, mortality, distributions, and food web interactions of a wide range of organisms in the Chesapeake Bay (e.g., Breitburg et al., 2003; Kemp et al., 2005). Seasonal hypoxia results in mortality of benthic animals in the deeper parts of the Bay, such that deep benthic macrofauna are essentially absent in the summer and depauperate during other times of the year (e.g., Sagasti et al., 2001). Mortality of animals can also occur in shallow water environments with episodic advection of hypoxic or anoxic bottom water shoreward (Breitburg, 1990) and where warm, calm conditions result in diel hypoxic events in shallow waters (Tyler and Targett, 2007).

In addition to increasing mortality directly, hypoxia may have strong effects on the ecosystem and its fisheries through behavioral and physiological responses of organisms that alter trophic interactions over broad time and space scales (Breitburg et al., 2001). For example, increases in summer temperatures and increased anoxia or hypoxia may exclude species such as striped bass and Atlantic sturgeon (Acipenser oxyrhynchus) from benthic feeding grounds and bioenergetically favorable cool deep-water environments (Coutant, 1985; Secor and Gunderson, 1998). In a simulation on the combined effects of hypoxia and temperature, Niklitschek and Secor (2005) observed that even a small overall warming $\left(1^{\circ} \mathrm{C}\right)$ during summer months could virtually eliminate suitable habitats for juvenile sturgeons (Fig. 11). Low dissolved oxygen can also alter trophic interactions that support fishery species by inhibiting production of ecologically important zooplankton grazers (Roman et al., 1993), increasing some species' susceptibility to predation (e.g., Breitburg et al., 1997), and providing predatory refuge to others (Sagasti et al., 2001). Repeated exposure of deeper subtidal oyster populations off Calvert Cliffs, Maryland to low-oxygen bottom water resulted in depressed growth rates relative to rates noted for oysters in shallower depths where exposure to low-oxygen water was less frequent (Osman and Abbe, 1994).

Warming will increase the extent and severity of effects of hypoxia on macrofauna by affecting dissolved $\mathrm{O}_{2}$ concentrations as discussed in Section 5.4, but also by increasing the oxygen requirements of fishes (e.g., Shimps et al., 2005). The combined effect is very likely to be a further reduction in the quality and spatial extent of suitable habitat in the Chesapeake Bay system for a wide range of aerobic organisms. 


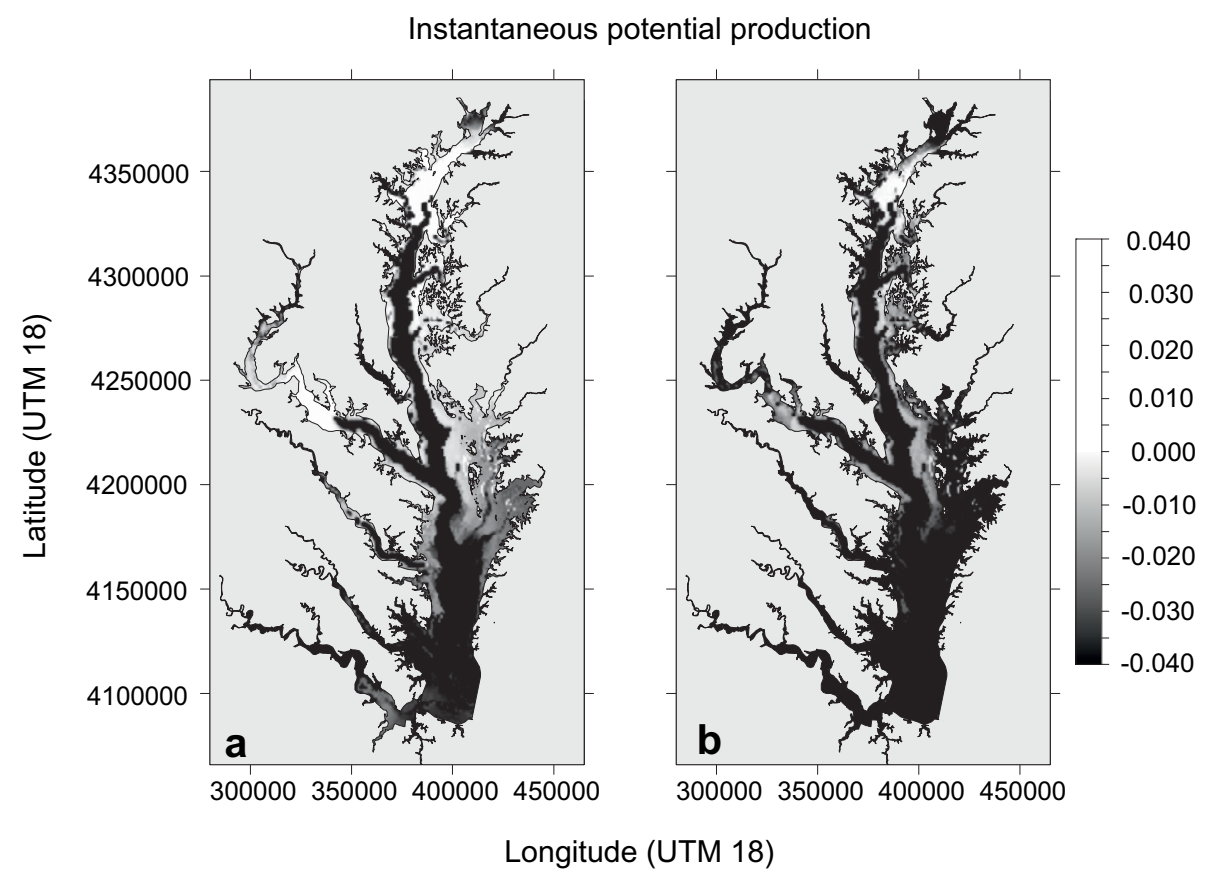

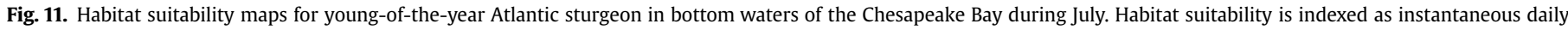

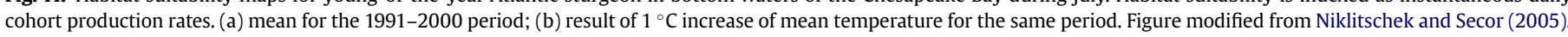

\subsection{Other impacts on fish and shellfish}

Among the greatest concerns about climate change effects on fish and shellfish is the consequence of sea-level rise on tidal wetlands (Section 6.2). Reductions in tidal marsh and submersed vegetation directly affect the Bay's fisheries because many fishes and crustaceans utilize these habitats as nursery areas and foraging grounds (e.g., Boesch and Turner, 1984; Kneib and Wagner, 1994). Ecologically and economically important species that utilize these habitats include forage fishes such as mummichog (Fundulus heteroclitus), eastern mosquitofish (Gambusia holbrooki), and predatory nekton such as summer flounder, spotted seatrout, striped bass, and blue crabs. Because many of these species spend much of their life spans in the coastal Atlantic, significant loss or degradation of these habitats could also affect the larger-scale Northeast U.S. continental shelf large marine ecosystem.

There is an indication that intense storms in the Chesapeake Bay region may increase in the future (Section 2.6) and the impacts on fisheries could be dramatic. For example, strong winds associated with storms influence how larval fish and crabs move into and out of the Chesapeake Bay. Summer and fall tropical storms favor the dispersal of larval Atlantic croaker into the Chesapeake Bay resulting in higher juvenile counts during the subsequent winter and summer (Houde et al., 2005; Montane and Austin, 2005). Blue crabs spawn in coastal waters adjacent to the mouth of the Chesapeake, and depend upon northward and westward winds to transport their offspring back into the Chesapeake (Olmi, 1995). Such transport can be aided or curtailed by tropical storm activity. For similar reasons, winter storm activity can influence dispersal into the Chesapeake and subsequent nursery habitat use by coastal spawning fish such as menhaden and spot (Epifanio and Garvine, 2001).

Bivalves, as well as a number of other organisms such as foraminifera, rely on $\mathrm{pH}$-sensitive processes to build calcium carbonate shells and other structures. Therefore $\mathrm{CO}_{2}$ increases could dramatically alter calcification in these animals (Gazeau et al., 2007). Consistent with this pattern, Miller et al. (2009) found that Chesapeake Bay eastern oyster larvae reared in experimental aquaria under atmospheric $\mathrm{CO}_{2}$ levels that could be reached this century (560 ppm and 800 ppm, Fig. 2b) grew and calcified more slowly than under ambient atmospheric conditions when temperature, salinity, light level, day/night cycle, and food quality/ quantity were held constant.

\section{Discussion and summary}

The overall picture that emerges from the above review is that climate variability has influenced a multitude of physical, chemical, and biological processes in the Chesapeake Bay and that future changes in climate will profoundly influence the Bay. Uncertainty varies dramatically, however, among the various potential impacts because (1) the uncertainty in future climate forcing of the Chesapeake Bay region varies dramatically among the proximate forcing agents (atmospheric $\mathrm{CO}_{2}$, water temperature, sea level, and streamflow) and (2) the uncertainty in the sensitivity of Bay system components to climate varies dramatically among the forcing agents and the components. In the remainder of this section, we summarize projections of climate change in the Bay region and their impacts on the Bay, emphasizing the degree of certainty and thus prioritizing future research needs.

With regard to climate forcing agents, much greater certainty exists for projected trends in atmospheric $\mathrm{CO}_{2}$, water temperature and sea level (all virtually certain to increase) than for storminess (likely to increase) and annual streamflow (about as likely to increase as not). However, it does appear likely that winter and spring streamflow will increase. Further, heat waves and precipitation intensity are likely to increase, which will likely result in greater extremes (high and low) of streamflow. The greatest research needs are thus for improved precipitation and streamflow projections and for robust error bounds on these and other projections (e.g., Tebaldi et al., 2005). A better understanding is also required of the causes of $20^{\text {th }}$-century changes in precipitation and temperature in the Bay watershed.

With regard to the biogeochemistry of the Bay watershed, a fundamental problem is the lack of a mechanistic understanding 
of nutrient cycling on the watershed scale, which is demonstrated by the current controversy about temperature vs. precipitation impacts on nutrient fluxes averaged over many years (Howarth et al., 2006; Schaefer and Alber, 2007). It is likely that nutrient and sediment loading during winter and spring will increase because flow will likely increase during this time. Also, given no change in the annual flow regime, it is likely that phosphorus and sediment loading will increase as a result of the more intense and potentially less frequent rain events. However, a quantitative relationship between particle loading and precipitation intensity remains to be established. Over a longer time period, changes in the land use and land cover across the Bay watershed (caused, in part, by climate change) may dominate the change in flux. Research is needed to better quantify current material budgets (such as reducing uncertainty in atmospheric $\mathrm{N}$ deposition estimates) and to develop robust mechanistic and quantitative models of large-scale watershed nutrient and sediment cycling (with some species-specific representation) that can be applied over a variety of time scales (daily to decadal). Of particular importance is an improved understanding of the combined impacts of climate and land-use and land-cover change, including climate impacts on human infrastructure (e.g., storm water management systems or, more speculatively, concentrated animal feeding operations).

Despite all of the research on the physical oceanography of the Chesapeake Bay, little is known about its seasonal and interannual characteristics, the time scales most relevant for climate change. Summertime stratification and landward advection below the pycnocline are likely to increase in response to increases in winterspring streamflow, but other circulation responses to climate, such as those due to changes in winds and sea level, are poorly known because of the uncertainty in the climate change itself as well as the lack of research on the response of estuarine physics to climate change. Salinity will very likely increase in response to sea-level rise and warming alone (due to increased evapotranspiration and thus decreased streamflow), but the lack of consensus in annual precipitation changes makes the overall direction of salinity change highly uncertain. Increases in salinity variability are possible on the seasonal time scale (if summers do not get wetter) and are likely on the interannual time scale (due to droughts). The relationship of sediment loading to flow is well constrained on annual time scales but not for extreme events. The connection between other sediment sources and climate is poorly known. Predictive modeling of extreme temperature events, which are important for SAV and likely other organisms, is lacking, as is predictive modeling of wind patterns, directions and strengths, which are important for holoand meroplankton advection but also summer productivity maxima. A dedicated research program combining observations and models is needed for a better understanding of these complex estuarine physical processes under the changing conditions anticipated for the next century.

Current research suggests that climate-induced increases in winter and spring nutrient loading to the Bay will likely result in increasing phytoplankton production. Combined with higher temperatures that promote decreased oxygen solubility and greater heterotrophy, this increase in phytoplankton production will likely lead to more intense and more frequent episodes of hypoxia. Higher temperatures and $\mathrm{CO}_{2}$ levels appear likely to select for increases in harmful algal blooms. Though the direction of many trends is fairly certain, quantitative relationships are few, particularly for temperature impacts, which, at interannual time scales, have been overwhelmed in many cases by streamflow impacts. Thus, we have very few whole-system views of the response of Bay biogeochemistry to temperature. This is unfortunate because estuarine biogeochemical processes are complex and highly non-linear, and efforts to untangle the biogeochemical impacts of multiple climate forcings (temperature, $\mathrm{CO}_{2}$, streamflow, sea level) from each other and from other forcing agents (e.g., land-use and land cover change) will require long-term attention and dedicated resources.

Field observations and experiments have illustrated the high sensitivity of Bay vascular plants to temperature, salinity, light, $\mathrm{CO}_{2}$, and sea level, and the complexity of the interactions among these forcing agents is just beginning to be understood. For example, it is clear that eelgrass is likely to respond positively to the direct effects of higher atmospheric $\mathrm{CO}_{2}$ levels, but not if water clarity is unimproved or is further degraded by the likely increases in precipitation intensity. Similar to SAV, estuarine wetlands will respond positively to higher $\mathrm{CO}_{2}$ levels, but this response may be overwhelmed by inundation due to sea-level rise and changes in land use and land cover. In summary, research is needed to capture the implications of multiple interacting stressors that will influence the distribution and abundance of Bay vascular plants in the future.

While some consequences of climate change on fish and shellfish may be positive (such as increases in species with more southerly distributions), it appears that most impacts (such as increased hypoxia and $\mathrm{CO}_{2}$ ) will be negative. However, there is great uncertainty in the response of higher trophic levels in the Bay to climate change because of the accumulated uncertainty in projected changes in climate, watershed hydrology and biogeochemistry, lower trophic levels, and pathogens. Further compounding this uncertainty is the high non-linearity inherent in trophic interactions and faunal life cycles. As with other Bay living resources, whole-system approaches involving monitoring, process studies, and numerical modeling will be required to develop a quantitative understanding of the impacts of climate change on fish and shellfish.

Climate change in the Chesapeake Bay region has the potential to create cultural and socio-economic impacts on a wide range of stakeholders, including commercial watermen, farmers, property owners, and municipal and county governments. To date, no systematic research has been undertaken to investigate how climate change will impact cultural and socio-economic processes, and vice versa across the Bay region. The hydrologic, biogeochemical, physical, and living resources impacts described in this review present a number of areas where livelihoods may be affected and there is the potential for a wide range of social and economic impacts, particularly on weather-dependent industries and entities subject to air or water quality regulation.

An important component of any social science research agenda on climate change will be the assessment of local knowledge and perceptions of climate change. This is because local knowledge may be able to identify impacts that are occurring long before these impacts are noticed by the scientific community, and local knowledge can be used to extend the reach of scientific inquiry into analysis of impacts on livelihoods, communities, and land use practices. Also, local populations will have cultural perceptions of climate change that may not match well with the models of climate change and impacts deployed by scientists and policymakers, thus raising the possibility that information produced by science and policy may not be effective in changing behaviors or alleviating impacts related to climate change goals.

In summary, the Chesapeake Bay system has shown a high sensitivity to climate variability and is thus likely, given current climate projections, to behave very differently in the future, even if other important influences (e.g., land use change and fisheries) remain unchanged. The majority of climate change impacts are negative, and thus climate change presents a serious challenge to current efforts to restore the Chesapeake Bay. However, there is a wide divergence in possible climate futures (perhaps even wider than shown in Fig. 2), and thus we emphasize that, although it is very likely that climate change impacts will occur, it is also clear that the severity of these impacts are directly under human control. 
Efforts to reduce $\mathrm{CO}_{2}$ emissions now will thus reduce future climate change impacts on the Chesapeake Bay and other estuaries.

We recommend a common strategy for addressing the gaps in understanding about Bay physical processes, biogeochemistry, living resources, and human systems: a coordinated program of long-term research based on a whole-system approach linking monitoring, process studies, and numerical modeling. Such a program can and should be designed around specific near- and long-term research objectives and designed to yield fundamental improvements in understanding of these systems. The scope of the issues facing the Chesapeake Bay requires that the recommended program reflect a diverse, interdisciplinary, multi-institution approach with a foundation of new, dedicated resources and strong institutional relationships between Bay managers and decision makers.

Other estuaries will respond differently to climate change than the Chesapeake Bay, and so our findings cannot be directly applied to other systems. There are three main reasons for this. First, estuaries themselves have a tremendous variety in their physical, chemical, and biological characteristics; these characteristics range, for example, from well mixed to stratified, from light-limited to nutrient limited, and from well oxygenated to seasonally anoxic. Second, estuaries vary dramatically in the ways and degree to which they have been influenced by human activity, such as nutrient over-enrichment, changes in sediment loading, shoreline hardening, and overfishing. These two factors characterize the current state of an estuary and, given the highly non-linear way in which estuaries respond to external forcing (Kemp et al., 2005; Kemp and Goldman, 2008), their response to climate change will very likely depend strongly on their initial state. A dramatic example of this is comparison of the partially stratified, nutrientlimited Chesapeake with its neighbor to the north, the Delaware Bay, which is well mixed and light-limited. Whereas projected winter-spring streamflow increases into the Chesapeake would likely lead to a stronger spring phytoplankton bloom and greater summertime anoxia, we might expect that such a streamflow change would decrease phytoplankton production and have little or no effect on oxygen levels in the Delaware Bay.

The third reason that other estuaries will respond differently to climate change than the Chesapeake Bay will is that the climate change itself will differ, though with differing degrees among the forcing agents. For example, while all estuaries will experience essentially the same higher levels of atmospheric $\mathrm{CO}_{2}$ in the future, the degree of warming and sea-level rise will vary regionally and seasonally. More importantly, however, streamflow changes will vary dramatically with region in terms of magnitude and timing. Subtropical estuaries will very likely see decreases in annual streamflow due to the combined impact of decreased precipitation and higher evapotranspiration. Subpolar estuaries will see reductions in spring streamflow as a result of decreases in snowfall and earlier melting of snow on land.

The main aspect of the current study can be generalized to other estuaries is the approach, which may be the most novel feature of our work. There is a diverse body of research on the impacts of climate change on estuaries, but very little of it-including aspects related to climate change itself and implications for watershed processes, estuarine circulation, biogeochemistry, vascular plants, and fisheries-has been synthesized for one system to create a holistic picture of the impacts and place them in the context of other stressors (e.g., land-use change) and restoration efforts. This work was made possible by bringing together scientists with regional expertise in a wide diversity of environmental sciences, including climate, forestry, hydrology, biogeochemistry, wetland ecology, hydrodynamics, plankton ecology, fisheries, and human/environment interactions. Efforts such as this in other estuaries, followed by cross- comparisons among these estuaries, may be the most fruitful path to a generalized theory of the impacts of climate change on estuaries.

\section{Acknowledgments}

We are grateful for input and encouragement from the Science and Technical Advisory Committee of the Chesapeake Bay Program. Critical comments from M. Castro, S. Crate, T. Johnson, D. Kimmel, and J. Shen on an early version of this paper are appreciated. Two anonymous reviewers were helpful in improving the manuscript.

\section{References}

Aber, J., McDowell, W., Nadelhoffer, K., Magill, A., Berntson, G., Kamakea, M., McNulty, S., Currie, W., Rustad, L., Fernandez, I., 1998. Nitrogen saturation in temperate forest ecosystems. BioScience 48, 921-934.

Adolf, J.E., Krupatkina, D., Bachvaroff, T., Place, A.R., 2007. Karlotoxin mediates grazing by Oxyrrhis marina on strains of Karlodinium veneficum. Harmful Algae 6, 400-412.

Adolf, J.E., Yeager, C.L., Miller, W.D., Mallonee, M.E., Harding, L.W., 2006. Environmental forcing of phytoplankton floral composition, biomass, and primary productivity in Chesapeake Bay, USA. Estuarine, Coastal and Shelf Science 67, $108-122$.

Allard, J., Keim, B.D., 2007. Spuriously induced temperature trends in the Southeast United States. Theoretical and Applied Climatology 88, 103-110.

Andrews, J.D., 1996. History of Perkinsus marinus, a pathogen of oysters in Chesapeake Bay 1950-1984. Journal of Shellfish Research 15, 13-16.

Austin, H.M., 2002. Decadal oscillations and regime shifts: A characterization of the Chesapeake Bay marine climate. American Fisheries Society Symposium 32, 155-170.

Bambrick, H.J., Kjellstrom, T.E., 2004. Good for your heart but bad for your baby? Revised guidelines for fish consumption in pregnancy. The Medical Journal of Australia 181, 61-62.

Bauer, L.J., 2006. Winter mortality of the blue crab (Callinectes sapidus) in the Chesapeake Bay. Masters thesis, University of Maryland.

Beer, S., Koch, E., 1996. Photosynthesis of marine macroalgae and seagrasses in globally changing $\mathrm{CO}_{2}$ environments. Marine Ecology Progress Series 141, 199-204.

Bintz, J.C., Nixon, S.W., Buckley, B.A., Granger, S.L., 2003. Impacts of temperature and nutrients on coastal lagoon plant communities. Estuaries and Coasts 26, 765-776.

Boesch, D.F., (editor) 2008. Global Warming and the Free State: Comprehensive Assessment of Climate Change Impacts in Maryland. Report of the Scientific and Technical Working Group of the Maryland Commission on Climate Change. University of Maryland Center for Environmental Science, Cambridge, Maryland.

Boesch, D.F., Turner, R.E., 1984. Dependence of fishery species on salt marshes: the role of food and refuge. Estuaries and Coasts 7, 460-468.

Booth, S., Zeller, D., 2005. Mercury, food webs, and marine mammals: implications of diet and climate change for human health. Environmental Health Perspectives 113, 521-526.

Boyer, E.W., Howarth, R.W., 2008. Nitrogen fluxes from rivers to the coastal oceans. In: Capone, D.G., Bronk, D., Mulholland, M., Carpenter, E.J. (Eds.), Nitrogen in the Marine Environment, second ed. Academic Press, San Diego, pp. 1565-1587.

Boynton, W.R., Kemp, W.M., 2000. Influence of river flow and nutrient loads on selected ecosystem processes: a synthesis of Chesapeake Bay data. In: Hobbie, J.E. (Ed.), Estuarine Science: A Synthetic Approach to Research and Practice. Island Press, Washington, D.C, pp. 269-298.

Breitburg, D.L., 1990. Near-shore hypoxia in the Chesapeake Bay: patterns and relationships among physical factors. Estuarine, Coastal and Shelf Science 30, 593-609.

Breitburg, D.L., 2002. Effects of hypoxia, and the balance between hypoxia and enrichment, on coastal fishes and fisheries. Estuaries 25, 767-781.

Breitburg, D.L., Adamack, A., Rose, K.A., Kolesar, S.E., Decker, B., Purcell, J.E. Keister, J.E., Cowan, J.H., 2003. The pattern and influence of low dissolved oxygen in the Patuxent River, a seasonally hypoxic estuary. Estuaries and Coasts 26, 280-297.

Breitburg, D.L., Fulford, R.S., 2006. Oyster-sea nettle interdependence and altered control within the Chesapeake Bay ecosystem. Estuaries and Coasts 29, 776-784.

Breitburg, D.L., Loher, T., Pacey, C.A., Gerstein, A., 1997. Varying effects of low dissolved oxygen on trophic interactions in an estuarine food web. Ecological Monographs 67, 489-507.

Breitburg, D.L., Pihl, L., Kolesar, S.E., 2001. Effects of low dissolved oxygen on the behavior, ecology and harvest of fishes: a comparison of the Chesapeake Bay and Baltic-Kattegat systems. In: Rabalais, N.N., Turner, R.E. (Eds.), Coastal Hypoxia: Consequences for Living Resources and Ecosystems. American Geophysical Union, Washington, DC, pp. 241-267.

Brooks, R.P., Wardrop, D.H., Bishop, J.A., 2004. Assessing wetland condition on a watershed basis in the Mid-Atlantic Region using synoptic land-cover maps. Environmental Monitoring and Assessment 94, 9-22.

Brookshire, E.N.J., Valett, H.M., Thomas, S.A., Webster, J.R., 2007. Atmospheric N deposition increases organic N loss from temperate forests. Ecosystems 10, 252-262. 
Burkett, V., Kusler, J., 2000. Climate change: Potential impacts and interactions in wetlands of the United States. Journal of the American Water Resources Association 36, 313-320.

Burrell, V.G., Van Engel, W.A., 1976. Predation by and distribution of a ctenophore, Mnemiopsis leidyi (A. Agassiz), in the York River estuary. Estuarine and Coastal Marine Science 4, 235-242.

Castro, M.S., Driscoll, C.T., Jordan, T.E., Reay, W.G., Boynton, W.R., 2003. Sources of nitrogen to estuaries in the United States. Estuaries and Coasts 26, 803-814.

Cerco, C.F., Noel, M.R., Linker, L., 2004. Managing for water clarity in Chesapeake Bay. Journal of Environmental Engineering 130, 631-642.

Chambers, R.M., Meyerson, L.A., Saltonstall, K., 1999. Expansion of Phragmites australis into tidal wetlands of North America. Aquatic Botany 64, 261-273.

Chesapeake Bay Foundation, 2007. Climate Change and the Chesapeake Bay: Challenges, Impacts, and the Multiple Benefits of Agricultural Conservation Work. Chesapeake Bay Foundation, Annapolis, MD, 18 pp.

Chesapeake Bay Program, 2003. Bay Program partners adopt new innovative approach to restoring water quality in Chesapeake Bay, Press Release, April 15, 2003. Annapolis, MD

Christensen, J.H., Hewitson, B., Busuioc, A., Chen, A., Gao, X., Held, I., Jones, R. Kolli, R.K., Kwon, W.T., Laprise, R., Rueda, V.M., Mearns, L., Menéndez, C.G., Räisänen, J., Rinke, A., Sarr, A., Whetton, P., 2007. Regional climate projections. In: Solomon, S., Qin, D., Manning, M., Chen, Z., Marquis, M., Averyt, K.B., Tignor, M., Miller, H.L. (Eds.), Climate Change 2007: The Physical Science Basis. Contribution of Working Group I to the Fourth Assessment Report of the Intergovernmental Panel on Climate Change. Cambridge University Press, Cambridge, United Kingdom and New York, NY, USA, pp. 847-940

Church, J.A., White, N.J., Coleman, R., Lambeck, K., Mitrovica, J.X., 2004. Estimates of the regional distribution of sea level rise over the 1950-2000 period. Journal of Climate 17, 2609-2625.

Colwell, R.R., 1996. Global climate and infectious disease: the cholera paradigm. Science 274, 2025-2031.

Conover, D.O., Present, T.M.C., 1990. Countergradient variation in growth rate: compensation for length of the growing season among Atlantic silversides from different latitudes. Oecologia 83, 316-324.

Cook, T., Folli, M., Klinck, J., Ford, S., Miller, J., 1998. The relationship between increasing sea-surface temperature and the northward spread of Perkinsus marinus (Dermo) disease epizootics in oysters. Estuarine, Coastal and Shelf Science 46, 587-597.

Coutant, C.C., 1985. Striped Bass, temperature, and dissolved oxygen: a speculative hypothesis for environmental risk. Transactions of the American Fisheries Society $114,31-61$.

Cowan Jr., J.H., Houde, E.D., 1993. Relative predation potentials of scyphomedusae, ctenophores and planktivorous fish on ichthyoplankton in Chesapeake Bay. Marine Ecology Progress Series 95, 55-65.

Cronin, T.M., Dwyer, G.S., Kamiya, T., Schwede, S., Willard, D.A., 2003. Medieval Warm Period, Little Ice Age and 20th century temperature variability from Chesapeake Bay. Global and Planetary Change 36, 17-29.

Davis, A., 2007. Stormwater. Impacts of Growth on Water Quality Scientific Summit Annapolis, MD

Davis, J.L., Mitrovica, J.X., 1996. Glacial isostatic adjustment and the anomalous tide gauge record of eastern North America. Nature 379, 331-333.

Dingerson, L.M., 2005. Predicting future shoreline condition based on land use trends, logistic regression, and fuzzy logic. Masters thesis, Virginia Institute of Marine Science, The College of William and Mary.

Dukes, J.S., 2007. Tomorrow's plant communities: different, but how? New Phytologist 176, 235-237.

Edwards, M., Richardson, A.J., 2004. Impact of climate change on marine pelagic phenology and trophic mismatch. Nature 430, 881-884.

Ehlers, A., Worm, B., Reusch, T.B.H., 2008. Importance of genetic diversity in eelgrass Zostera marina for its resilience to global warming. Marine Ecology Progress Series 355, 1-7.

Epifanio, C.E., Garvine, R.W., 2001. Larval transport on the Atlantic continental shelf of North America: a review. Estuarine, Coastal and Shelf Science 52, 51-77.

Erickson, J.E., Megonigal, J.P., Peresta, G., Drake, B.G., 2007. Salinity and sea leve mediate elevated $\mathrm{CO}_{2}$ effects on $\mathrm{C}_{3}-\mathrm{C}_{4}$ plant interactions and tissue nitrogen in a Chesapeake Bay tidal wetland. Global Change Biology 13, 202-215.

Eshleman, K.N., Gardner, R.H., Seagle, S.W., Castro, N.M., Fiscus, D.A., Webb, J.R., Galloway, J.N., Deviney, F.A., Herlihy, A.T., 2000. Effects of disturbance on nitrogen export from forested lands of the Chesapeake Bay Watershed. Environmental Monitoring and Assessment 63, 187-197.

Field, J.C., Boesch, D.F., Scavia, D., Buddemeier, R., Burkett, V.R., Cayan, D. Fogarty, M., Harwell, M., Howarth, R., Mason, C., 2001. Potential consequences of climate variability and change on coastal areas and marine resources. In: National Assessment Synthesis Team (Ed.), Climate Change Impacts on the United States: The Potential Consequences of Climate Variability and Change Report for the US Global Change Research Program. Cambridge University Press, Cambridge, UK, pp. 461-487.

Frank, K.T., Perry, R., Drinkwater, K.F., 1990. Predicted response of Northwest Atlantic invertebrate and fish stocks to $\mathrm{CO}_{2}$-induced climate change. Transactions of the American Fisheries Society 119, 353-365.

Fu, F.X., Warner, M.E., Zhang, Y., Feng, Y., Hutchins, D.A., 2008a. Effects of increased temperature and $\mathrm{CO}_{2}$ on photosynthesis, growth, and elemental ratios in marine Synechococcous and Prochlorococcus (Cyanobacteria). Journal of Phycology 43, 485-496.
Fu, F.X., Zhang, Y., Warner, M.E., Feng, Y., Sun, J., Hutchins, D.A., 2008b. A comparison of future increased $\mathrm{CO}_{2}$ and temperature effects on sympatric Heterosigma akashiwo and Prorocentrum minimum. Harmful Algae 7, 76-90.

Gazeau, F., Quiblier, C., Jansen, J.M., Gattuso, J.P., Middelburg, J.J., Heip, C.H.R., 2007. Impact of elevated $\mathrm{CO}_{2}$ on shellfish calcification. Geophysical Research Letters 34. L07603 doi:10.1029/2006GL028554.

Gibson, J.R., Najjar, R.G., 2000. The response of Chesapeake Bay salinity to climateinduced changes in streamflow. Limnology and Oceanography 45, 1764-1772.

Gitay, H., Brown, S., Easterling, W., Jallow, B., 2001. Chapter 5: ecosystems and their goods and services. In: McCarthy, J.J., Canziani, O.F., Leary, N.A., Dokken, D.J., White, K.S. (Eds.), Climate Change 2001: Impacts, Adaptation and Vulnerability. Cambridge University Press, Cambridge, U.K, pp. 235-342.

Gray, D.R., 2004. The gypsy moth life stage model: landscape-wide estimates of gypsy moth establishment using a multi-generational phenology model. Ecological Modelling 176, 155-171.

Greve, T.M., Borum, J., Pedersen, O., 2003. Meristematic oxygen variability in eelgrass (Zostera marina). Limnology and Oceanography 48, 210-216.

Groisman, P.Y., Knight, R.W., Karl, T.R., 2001. Heavy precipitation and high streamflow in the contiguous United States: Trends in the twentieth century. Bulletin of the American Meteorological Society 82, 219-246.

Groisman, P.Y., Knight, R.W., Karl, T.R., Easterling, D.R., Sun, B.M., Lawrimore, J.H., 2004. Contemporary changes of the hydrological cycle over the contiguous United States: trends derived from in situ observations. Journal of Hydrometeorology $5,64-85$.

Hagy, J.D., 2002. Eutrophication, hypoxia and trophic transfer efficiency in Chesapeake Bay. Ph.D. thesis, University of Maryland.

Hagy, J.D., Boynton, W.R., Keefe, C.W., Wood, K.V., 2004. Hypoxia in Chesapeake Bay, 1950-2001: Long-term change in relation to nutrient loading and river flow. Estuaries 27, 634-658

Harding, L.W., 1994. Long-term trends in the distribution of phytoplankton in Chesapeake Bay: roles of light, nutrients, and streamflow. Marine Ecology Progress Series 104, 267-291.

Hare, J.A., Able, K.W., 2007. Mechanistic links between climate and fisheries along the east coast of the United States: explaining population outbursts of Atlantic croaker (Micropogonias undulatus). Fisheries Oceanography 16, 31-45.

Harvey, H.R., ÓHara, S.C.M., Eglinton, G., Corner, E.D.S., 1989. The comparative fate of dinosterol and cholesterol in copepod feeding: implications for a conservative molecular biomarker in the marine water column. Organic Geochemistry 14, 635-641.

Haven, D., 1987. The American oyster Crassostrea virginica in Chesapeake Bay. In: Majumdar, S.K., Hall, L.W.J., Austin, H.M. (Eds.), Contaminant Problems and Management of Living Chesapeake Bay Resources. The Pennsylvania Academy of Sciences, Philadelphia, pp. 165-176.

Hayhoe, K., Wake, C.P., Huntington, T.G., Luo, L.F., Schwartz, M.D., Sheffield, J., Wood, E., Anderson, B., Bradbury, J., DeGaetano, A., Troy, T.J., Wolfe, D., 2007. Past and future changes in climate and hydrological indicators in the US Northeast. Climate Dynamics 28, 381-407.

Hettler, W.F., 1992. Correlation of winter temperature and landings of pink shrimp Penaeus duorarum in North Carolina. Fishery Bulletin 90, 405-406.

Hilton, T.W., Najjar, R.G., Zhong, L., Li, M., 2008. Is there a signal of sea-level rise in Chesapeake Bay salinity? Journal of Geophysical Research 113, C09002. doi:10.1029/2007JC004247.

Hirsch, M.E., DeGaetano, A.T., Colucci, S.J., 2001. An east coast winter storm climatology. Journal of Climate 14, 882-899.

Hirschberg, D.J., Schubel, J.R., 1979. Recent geochemical history of flood deposits in the Northern Chesapeake Bay. Estuarine and Coastal Marine Science 9, 771-784.

Houde, E.D., Bichy, J., Jung, S., 2005. Effects of hurricanes on Atlantic croaker (Micropogonias undulates) recruitment to Chesapeake Bay. In: Sellner, K.G. (Ed.) Hurricane Isabel in Perspective. Chesapeake Research Consortium, Edgewater Maryland, pp. 5-160.

Houghton, J.T., Ding, Y., Griggs, D.J., Noguer, M., van der Linden, P.J., Dai, X., Maskell, K., Johnson, C.A. (Eds.), 2001. Climate Change 2001: The Scientific Basis. Contribution of Working Group I to the Third Assessment Report of the Intergovernmental Panel on Climate Change. Cambridge University Press, Cambridge, United Kingdom and New York, NY, USA, 881 pp.

Howarth, R.W., 2006. Atmospheric deposition and nitrogen pollution in coastal marine ecosystems. In: Visgilio, G.R., Whitelaw, D.M. (Eds.), Acid in the Environment: Lessons Learned and Future Prospects. Springer, New York, pp. 97-116.

Howarth, R.W., Swaney, D.P., Boyer, E.W., Marino, R., Jaworski, N., Goodale, C., 2006. The influence of climate on average nitrogen export from large watersheds in the Northeastern United States. Biogeochemistry 79, 163-186.

Hubert, B., Bacou, J., Belveze, H., 1989. Epidemiology of human anisakiasis: incidence and sources in France. The American Journal of Tropical Medicine and Hygiene 40, 301-303.

Hurst, T.P., Conover, D.O., 1998. Winter mortality of young-of-the-year Hudson River striped bass (Morone saxatilis): size-dependent patterns and effects on recruitment. Canadian Journal of Fisheries and Aquatic Sciences 55, 1122-1130.

IPCC, 2007. Summary for policymakers. In: Solomon, S., Qin, D., Manning, M., Chen, Z., Marquis, M., Averyt, K.B., Tignor, M., Miller, H.L. (Eds.), Climate Change 2007: The Physical Science Basis. Contribution of Working Group I to the Fourth Assessment Report of the Intergovernmental Panel on Climate Change. Cambridge University Press, Cambridge, United Kingdom and New York, NY, USA.

Iverson, L.R., Prasad, A.M., Schwartz, M.W., 2005. Predicting potential changes in suitable habitat and distribution by 2100 for tree species of the Eastern United States. Journal of Agricultural Meteorology 61, 29-37. 
Johnson, T., Kittle, J., 2007. Sensitivity analysis as a guide for assessing and managing the impacts of climate change on water resources. Water Resources IMPACT 8, 17-19.

Johnson, T.B., Evans, D.O., 1996. Temperature constraints on overwinter survival of age- 0 white perch. Transactions of the American Fisheries Society $125,466-471$.

Justić, D., Rabalais, N.N., Turner, R.E., 2003. Simulated responses of the Gulf of Mexico hypoxia to variations in climate and anthropogenic nutrient loading. Journal of Marine Systems 42, 115-126.

Kana, T.M., Lomas, M.W., MacIntyre, H.L., Cornwell, J.C., Gobler, C.J., 2004. Stimulation of the brown tide organism, Aureococcus anophagefferens, by selective nutrient additions to in situ mesocosms. Harmful Algae 3, 377-388.

Kaushal, S.S., Likens, G.E., Jaworski, N.A., Pace, M.L., Sides, A.M., Seekell, D., Belt, K.T. Secor, D.H., Wingate, R. Rising stream and river temperatures in the United States. Frontiers in Ecology and the Environment, in press.

Kearney, M.S., Stevenson, J.C., Ward, L.G., 1994. Spatial and temporal changes in marsh vertical accretion rates at Monie Bay: implications for sea-level rise. Journal of Coastal Research 10, 1010-1020.

Kemp, W.M., Batiuk, R., Bartleson, R., Bergstrom, P., Carter, V., Gallegos, C., Hunley, W., Karrh, L., Koch, E., Landwehr, J., Moore, K., Murray, L., Naylor, M. Rybicki, N., Stevenson, J.C., Wilcox, D., 2004. Habitat requirements for submerged aquatic vegetation in Chesapeake Bay: water quality, light regime, and physical-chemical factors. Estuaries 27, 363-377.

Kemp, W.M., Boynton, W.R., Adolf, J.E., Boesch, D.F., Boicourt, W.C., Brush, G., Cornwell, J.C., Fisher, T.R., Glibert, P.M., Hagy, J.D., 2005. Eutrophication of Chesapeake Bay: historical trends and ecological interactions. Marine Ecology Progress Series 303, 1-29.

Kemp, W.M., Goldman, E.B., 2008. Thresholds in the Recovery of Eutrophic Coastal Ecosystems. Chesapeake Bay Program and Maryland Sea Grant, 46 pp.

Kennedy, V.S., Mihursky, J.A., 1971. Upper temperature tolerances of some estuarine bivalves. Chesapeake Science 12, 193-204.

Kennedy, V.S., Twilley, R.R., Kleypas, J.A., Cowan Jr., J.H., Hare, S.R., 2002. Coastal and Marine Ecosystems and Global Climate Change: Potential Effects on U.S. Resources. Pew Center on Global Climate Change, Arlington, VA, 52 pp.

Kimmel, D.G., Miller, W.D., Roman, M.R., 2006. Regional scale climate forcing of mesozooplankton dynamics in Chesapeake Bay. Estuaries and Coasts 29, 375-387.

Kimmel, D.G., Newell, R.I.E., 2007. The influence of climate variation on eastern oyster (Crassostrea virginica) juvenile abundance in Chesapeake Bay. Limnology and Oceanography 52, 959-965.

Kneib, R.T., Wagner, S.L., 1994. Nekton use of vegetated marsh habitats at different stages of tidal inundation. Marine Ecology Progress Series 106, 227-238.

Lambert, S.J., Fyfe, J.C., 2006. Changes in winter cyclone frequencies and strengths simulated in enhanced greenhouse warming experiments: results from the models participating in the IPCC diagnostic exercise. Climate Dynamics 26, 713-728.

Langland, M., Cronin, T., Phillips, S., 2003. Executive summary. In: Langland, M., Cronin, T. (Eds.), A Summary Report of Sediment Processes in Chesapeake Bay and its Watershed. United States Geological Survey, New Cumberland, Pennsylvania, pp. 1-20.

Langland, M.J., Raffensperger, J.P., Moyer, D.L., Landwehr, J.M., Schwarz, G.E., 2006. Changes in Streamflow and Water Quality in Selected Nontidal Basins in the Chesapeake Bay Watershed, 1985-2004: U.S. Geological Survey Scientific Investigations Report 2006-5178, 75 pp.

Langley, J.A., McKee, K.L., Cahoon, D.R., Cherry, K.A., Megonigal, J.P., 2009. Elevated $\mathrm{CO}_{2}$ stimulates marsh elevation gain, counterbalancing sea-level rise. Proceedings of the National Academy of Sciences of the United States of America 106, 6182-6186.

Lomas, M.W., Glibert, P.M., Shiah, F.K., Smith, E.M., 2002. Microbial processes and temperature in Chesapeake Bay: current relationships and potential impacts of regional warming. Global Change Biology 8, 51-70.

Lotze, H.K., Worm, B., 2002. Complex interactions of climatic and ecological controls on macroalgal recruitment. Limnology and Oceanography 47, 1734-1741.

Lovett, G.M., Weathers, K.C., Arthur, M.A., 2002. Control of nitrogen loss from forested watersheds by soil carbon: nitrogen ratio and tree species composition. Ecosystems 5, 712-718.

Lowrance, R., Altier, L.S., Newbold, J.D., Schnabel, R.R., Groffman, P.M., Denver, J.M., Correll, D.L., Gilliam, J.W., Robinson, J.L., Brinsfield, R.B., Staver, K.W., Lucas, W., Todd, A.H., 1997. Water quality functions of riparian forest buffers in Chesapeake Bay watersheds. Environmental Management 21, 687-712.

Malone, T.C., 1992. Effects of water column processes on dissolved oxygen, nutrients, phytoplankton and zooplankton. In: Smith, D.E., Leffler, M., Mackiernan, G. (Eds.), Oxygen Dynamics in the Chesapeake Bay: A Synthesis of Recent Research. Maryland Sea Grant College, College Park, MD, pp. 61-112.

Malone, T.C., Conley, D.J., Fisher, T.R., Glibert, P.M., Harding, L.W., Sellner, K.G., 1996. Scales of nutrient-limited phytoplankton productivity in Chesapeake Bay. Estuaries 19, 371-385.

Malone, T.C., Kemp, W.M., Ducklow, H.W., Boynton, W.R., Tuttle, J.H., Jonas, R.B., 1986. Lateral variation in the production and fate of phytoplankton in a partially stratified estuary. Marine Ecology Progress Series 32, 149-160.

Manning, M.R., 2006. The treatment of uncertainties in the Fourth IPCC Assessment Report. Advances in Climate Change Research 2 (Suppl. 1), 13-21.

Marks, M., Lapin, B., Randall, J., 1994. Phragmites australis (P. communis): threats, management, and monitoring. Natural Areas Journal 14, 285-294.

Marshall, H.G., Egerton, T.A., 2009. The increasing occurrence and extended development of potentially harmful algal blooms in Virginia tidal rivers.
Proceedings of the 2009 Virginia Water Research Conference. Water Resources in Changing Climates. Richmond, VA.

Marshall, H.G., Egerton, T., Stem, T., Hicks, J., Kokocinski, M., 2004. Extended bloom concentrations of Dinophysis acuminata in Virginia estuaries during late winter through early spring, 2002. In: Steidinger, K.A., Landsberg, J.H., Tomas, C.R. Vargo, G.A. (Eds.), Harmful Algae 2002. Florida Fish \& Wildlife Conservation Commission, Florida Institute of Oceanography, IOC of UNESCO, St. Petersburg, FL, pp. 364-366.

Marshall, H.G., Nesius, K.K., 1996. Phytoplankton composition in relation to primary production in Chesapeake Bay. Marine Biology 125, 611-617.

McLaughlin, J.B., DePaola, A., Bopp, C.A., Martinek, K.A., Napolilli, N.P., Allison, C.G., Murray, S.L., Thompson, E.C., Bird, M.M., Middaugh, J.P., 2005. Outbreak of vibrio parahaemolyticus vastroenteritis associated with Alaskan oysters. New England Journal of Medicine 353, 1463-1470.

McMichael, A.J., Woodruff, R.E., Hales, S., 2006. Climate change and human health present and future risks. The Lancet 367, 859-869.

Meade, R.H., 1988. Movement and storage of sediment in river systems. In: Lerman, A., Meybeck, M. (Eds.), Physical and Chemical Weathering in Geochemical Cycles. Kluwer, Dordrecht, pp. 165-179.

Meehl, G.A., Stocker, T.F., Collins, W.D., Friedlingstein, P., Gaye, A.T., Gregory, J.M. Kitoh, A., Knutti, R., Murphy, J.M., Noda, A., Raper, S.C.B., Watterson, I.G. Weaver, A.J., Zhao, Z.C., 2007. Global climate projections. In: Solomon, S., Qin, D. Manning, M., Chen, Z., Marquis, M., Averyt, K.B., Tignor, M., Miller, H.L. (Eds.), Climate Change 2007: The Physical Science Basis. Contribution of Working Group I to the Fourth Assessment Report of the Intergovernmental Panel on Climate Change. Cambridge University Press, Cambridge, United Kingdom and New York, NY, USA, pp. 747-845.

Meyerson, L.A., Vogt, K.A., Chambers, R.M., 2002. Linking the success of Phragmites to the alteration of ecosystem nutrient cycles. In: Weinstein, M.P., Kreeger, D.A (Eds.), Concepts and Controversies in Tidal Marsh Ecology, Part 10: Success Criteria for Tidal Marsh Restoration. Kluwer Academic Publishers, New York, pp. $827-844$

Miller, A.W., Reynolds, A.C., Sobrino, C., Riedel, G.F., 2009. Shellfish face uncertain future in high $\mathrm{CO} 2$ world: Influence of acidification on oyster larvae calcification. PLoS ONE 4(5): e5661. doi:10.13761/journal.pone.00056661.

Montane, M.M., Austin, H.M., 2005. Effects of hurricanes on Atlantic croaker (Micropogonias undulatus) recruitment to Chesapeake Bay. In: Sellner, K.G. (Ed.) Hurricane Isabel in Perspective. Chesapeake Research Consortium, Edgewater Maryland, pp. 185-192.

Monteleone, D.M., Duguay, L.E., 2003. Laboratory studies of predation by the ctenophore Mnemiopsis leidyi on the early stages in the life history of the bay anchovy, Anchoa mitchilli. Journal of Plankton Research 10, 359-372.

Moore, K.A., Jarvis, J.C., 2008. Environmental factors affecting recent summertime eelgrass diebacks in the lower Chesapeake Bay: implications for long-term persistence. Journal of Coastal Research 55, 135-147.

Moore, K.A., Wetzel, R.L., 2000. Seasonal variations in eelgrass (Zostera marina L.) responses to nutrient enrichment and reduced light availability in experimental ecosystems. Journal of Experimental Marine Biology and Ecology 244, 1-28.

Moore, K.A., Wilcox, D.J., Orth, R.J., 2000. Analysis of the abundance of submersed aquatic vegetation communities in the Chesapeake Bay. Estuaries 23, 115-127.

Moore, M.V., Pace, M.L., Mather, J.R., Murdoch, P.S., Howarth, R.W., Folt, C.L. Chen, C.Y., Hemond, H.F., Flebbe, P.A., Driscoll, C.T., 1997. Potential effects of climate change on freshwater ecosystems of the New England/Mid-Atlantic Coastal Region. Climate Research 14, 161-173.

Moss, R.H., Malone, E.L., Ramachander, S., Perez, M.R., 2002. Climate Change Impacts: Maryland Resources at Risk. Maryland Energy Administration, 96 pp.

Mouriño-Pérez, R.R., Worden, A.Z., Azam, F., 2003. Growth of Vibrio cholerae 01 in red tide waters off California. Applied and Environmental Microbiology 69, 6923-6931.

Mulholland, M.R., Morse, R.E., Boneillo, G., Bernhardt, P.W., Filippino, K.C., Procise, L.A., Blanco-Garcia, J., Marshall, H.G., Egerton, T.A., Hunley, W.S Moore, K.A., Berry, D.L., Gobler, C.J., 2009. Understanding causes and impacts of the dinoflagellate, Cochlodinium polykrikoides, blooms in the Chesapeake Bay Estuaries and Coasts 32, 734-747.

Murdy, E.O., Birdsong, R.S., Musick, J.A., 1997. Fishes of the Chesapeake Bay. Smithsonian Institution Press, Washington, DC, 324 pp.

Muzzall, P.M., 1999. Nematode parasites of yellow perch, Perca flavescens, from the Laurentian Great Lakes. Journal of the Helminthological Society of Washington $66,115-122$.

Najjar, R.G., 1999. The water balance of the Susquehanna River Basin and its response to climate change. Journal of Hydrology 219, 7-19.

Najjar, R.G., 2009. Personal communication.

Najjar, R.G., Patterson, L., Graham, S., 2009. Climate simulations of major estuarine watersheds in the Mid-Atlantic region of the United States. Climatic Change 95 139-168.

Najjar, R.G., Walker, H.A., Anderson, P.J., Barron, E.J., Bord, R.J., Gibson, J.R., Kennedy, V.S., Knight, C.G., Megonigal, J.P., O'Connor, R.E., Polsky, C.D., Psuty, N.P., Richards, B.A., Sorenson, L.G., Steele, E.M., Swanson, R.S., 2000. The potential impacts of climate change on the mid-Atlantic coastal region. Climate Research 14, 219-233.

Nakićenović, N., Swart, R., 2000. Special Report on Emissions Scenarios. A Special Report of Working Group III of the Intergovernmental Panel on Climate Change. Cambridge University Press, Cambridge, United Kingdom and New York, NY, USA, 599 pp. 
National Marine Fisheries Service, 2001. Commercial Fisheries World Wide Web Page. http://www.st.nmfs.gov/st1/commercial/ (accessed September 2001).

National Oceanic and Atmospheric Administration, 1990. Estuaries of the United States: Vital Statistics of a National Resource Base. National Ocean Service, Ocean Assessments Division, Washington, D.C., 79 pp.

National Research Council, 2007. Mitigating Shore Erosion Along Sheltered Coasts. National Academy Press, Washington, D.C., 174 pp.

Neff, R., Chang, H.J., Knight, C.G., Najjar, R.G., Yarnal, B., Walker, H.A., 2000. Impact of climate variation and change on Mid-Atlantic Region hydrology and water resources. Climate Research 14, 207-218.

Niklitschek, E.J., Secor, D.H., 2005. Modeling spatial and temporal variation of suitable nursery habitats for Atlantic sturgeon in the Chesapeake Bay. Estuarine, Coastal and Shelf Science 64, 135-148.

Olmi, E.J., 1995. Ingress of blue crab megalopae in the York River, Virginia, 19871989. Bulletin of Marine Science 57, 753-780.

Orr, J.C., Fabry, V.J., Aumont, O., Bopp, L., Doney, S.C., Feely, R.A., Gnanadesikan, A., Gruber, N., Ishida, A., Joos, F., Key, R.M., Lindsay, K., Maier-Reimer, E. Matear, R., Monfray, P., Mouchet, A., Najjar, R.G., Plattner, G.K., Rodgers, K.B. Sabine, C.L., Sarmiento, J.L., Schlitzer, R., Slater, R.D., Totterdell, IJ., Weirig, M.F., Yamanaka, Y., Yool, A., 2005. Anthropogenic ocean acidification over the twenty-first century and its impact on calcifying organisms. Nature 437, 681-686.

Orth, R., Williams, M., Marion, S., Wilcox, D., Moore, K., Kemp, W.M., Batiuk, R Bergstrom, P., Carruthers, T., Rybicki, N., Dennison, W. Long term trends in submersed aquatic vegetation (SAV) in Chesapeake Bay related to water quality. Estuaries and Coasts, in review.

Orth, R.J., Moore, K.A. 1983. Chesapeake Bay: An unprecedented decline in submerged aquatic vegetation. Science 222, 51-53.

Osman, R.W., Abbe, G.R., 1994. Post-settlement factors affecting oyster recruitment in the Chesapeake Bay, USA. In: Dyer, K., Orth, R. (Eds.), Changes in Fluxes in Estuaries. Olsen \& Olsen, Denmark, pp. 335-340.

Paciorek, C.J., Risbey, J.S., Ventura, V., Rosen, R.D., 2002. Multiple indices of Northern Hemisphere cyclone activity, winters 1949-99. Journal of Climate 15 1573-1590.

Palacios, S.L., Zimmerman, R.C., 2007. Response of eelgrass Zostera marina to $\mathrm{CO}_{2}$ enrichment: possible impacts of climate change and potential for remediation of coastal habitats. Marine Ecology Progress Series 344, 1-13.

Peperzak, L., 2003. Climate change and harmful algal blooms in the North Sea. Acta Oecologica 24S, 139-144.

Perry, J.E., Hershner, C.H., 1999. Temporal changes in the vegetation pattern in a tidal freshwater marsh. Wetlands 19, 90-99.

Place, A.R., Saito, K., Deeds, J.R., Robledo, J.A.F., Vasta, G.R., 2008. A decade of research on Pfiesteria spp. and their toxins: unresolved questions and an alternative hypothesis. In: Botana, L.M. (Ed.), Seafood and Freshwater Toxins. CRC Press, New York, pp. 717-751.

Preston, B.L., 2004. Observed winter warming of the Chesapeake Bay estuary (1949-2002): Implications for ecosystem management. Environmenta Management 34, 125-139.

Puckett, B.J., Secor, D.H., Ju, S.J., 2008. Validation and application of lipofuscin-based age determination for Chesapeake Bay Blue Crabs Callinectes sapidus. Transactions of the American Fisheries Society 137, 1637-1649.

Purcell, J.E., 1992. Effects of predation by the scyphomedusan Chrysaora quinquecirrha on zooplankton populations in Chesapeake Bay, USA. Marine Ecology Progress Series 87, 65-76.

Purcell, J.E., Arai, M.N., 2000. Interactions of pelagic cnidarians and ctenophores with fish: a review. Hydrobiologia 451, 27-44.

Quinn, T.P., Adams, D.J., 1996. Environmental changes affecting the migratory timing of American Shad and Sockeye Salmon. Ecology 77, 1151-1162.

Rahmstorf, S., 2007. A semi-empirical approach to projecting future sea-level rise. Science 315, 368-370.

Rasse, D.P., Peresta, G., Drake, B.G., 2005. Seventeen years of elevated $\mathrm{CO}_{2}$ exposure in a Chesapeake Bay Wetland: Sustained but contrasting responses of plant growth and $\mathrm{CO}_{2}$ uptake. Global Change Biology 11, 369-377.

Ratti, S., Giordano, M., Morse, D., 2007. $\mathrm{CO}_{2}$-concentrating mechanisms of the potentially toxic dinoflagellate Protoceratium reticulatum (dinophyceae, Gonyaulacales). Journal of Phycology 43, 693-701.

Riebesell, U., Schulz, K.G., Bellerby, R.G.J., Botros, M., Fritsche, P., Meyerhofer, M. Neill, C., Nondal, G., Oschlies, A., Wohlers, J., 2007. Enhanced biological carbon consumption in a high $\mathrm{CO}_{2}$ ocean. Nature 450, 545-548.

Rogers, C.E., McCarty, J.P., 2000. Climate change and ecosystems of the Mid-Atlantic Region. Climate Research 14, 235-244.

Roman, M.R., Gauzens, A.L., Rhinehart, W.K., White, J.R., 1993. Effects of low oxygen waters on Chesapeake Bay zooplankton. Limnology and Oceanography 38 , 1603-1614.

Rombough, P.J., 1997. The effects of temperature on embryonic and larval development. In: Wood, C.M., McDonald, D.G. (Eds.), Global Warming: Implications for Freshwater and Marine Fish. Cambridge University Press, New York, NY, pp. 177-224.

Rome, M.S., Young-Williams, A.C., Davis, G.R., Hines, A.H., 2005. Linking temperature and salinity tolerance to winter mortality of Chesapeake Bay blue crabs (Callinectes sapidus). Journal of Experimental Marine Biology and Ecology 319 129-145.

Rose, J.B., Daeschner, S., Easterling, D.R., Curriero, F.C., Lele, S., Patz, J.A., 2000 Climate and waterborne disease outbreaks. Journal American Water Works Association 92, 77-87.
Rost, B., Richter, K., Riebesell, U., Hansen, P., 2006. Inorganic carbon acquisition in red tide dinoflagellates. Plant, Cell \& Environment 29, 810-822.

Sagasti, A., Schaffner, L.C., Duffy, J.E., 2001. Effects of periodic hypoxia on mortality, feeding and predation in an estuarine epifaunal community. Journal of Experimental Marine Biology and Ecology 258, 257-283.

Santamaría, L, van Vierssen, W. 1997. Photosynthetic temperature responses of fresh-and brackish-water macrophytes: a review. Aquatic Botany 58, 135-150.

Scavia, D., Field, J.C., Boesch, D.F., Buddemeier, R.W., Burkett, V., Cayan, D.R., Fogarty, M., Harwell, M.A., Howarth, R.W., Mason, C., Reed, D.J., Royer, T.C., Sallenger, A.H., Titus, J.G., 2002. Climate change impacts on US coastal and marine ecosystems. Estuaries 25, 149-164.

Schaefer, S.C., Alber, M., 2007. Temperature controls a latitudinal gradient in the proportion of watershed nitrogen exported to coastal ecosystems. Biogeochemistry $85,333-346$.

Schubel, J.R., Pritchard, D.W., 1986. Responses of Upper Chesapeake Bay to variations in discharge of the Susquehanna River. Estuaries 9, 236-249.

Secor, D.H., Gunderson, T.E., 1998. Effects of hypoxia and temperature on survival, growth, and respiration of juvenile Atlantic sturgeon, Acipenser oxyrinchus. Fishery Bulletin 96, 603-613.

Sellner, K.G., 1987. Phytoplankton in Chesapeake Bay: role in carbon, oxygen and nutrient dynamics. In: Majumdar, S.K., Hall Jr., L.W., Austin, H.M. (Eds.), Contaminant Problems and Management of Living Chesapeake Bay Resources. Pennsylvania Academy of Sciences, Philadelphia, PA, pp. 134-157.

Sellner, K.G., Olson, M.M., 1985. Copepod grazing in red tides of Chesapeake Bay. In: Anderson, D.M., White, A.W., Baden, D.G. (Eds.), Toxic Dinoflagellates. Elsevier, New York, pp. 245-251.

Sellner, K.G., Sawangwong, P., Dawson, R., Boynton, W.R., Kemp, W.M., Garber, J.H. 1992. Fate of dinoflagellates in Chesapeake Bay: Is sedimentation likely? In: Smayda, T.J. (Ed.), Marine Phytoplankton. Elsevier, New York, NY, pp. 825-830.

Sharpley, A.N. Hedley, MJ. Sibbesen, E, Hillbricht-Ilkowska, A, House, W.A. Ryszkowski, L., 1995. Phosphorus transfers from terrestrial to aquatic ecosystems. In: Tiessen, H. (Ed.), Phosphorus in the Global Environment. John Wiley, Chichester, UK, pp. 173-242.

Shimps, E.L., Rice, J.A., Osborne, J.A., 2005. Hypoxia tolerance in two juvenile estuary-dependent fishes. Journal of Experimental Marine Biology and Ecology $325,146-162$

Short, F.T., Neckles, H.A., 1999. The effects of global climate change on seagrasses. Aquatic Botany 63, 169-196.

Silvert, W., 1993. Size-structured models of continental shelf food webs. In: Christensen, V., Pauly, D. (Eds.), Trophic Models of Aquatic Ecosystems, ICLARM Conference Proceedings No. 26. ICLARM, Manila, Philippines, pp. 40-43.

Smith, E.M., Kemp, W.M., 1995. Seasonal and regional variations in plankton community production and respiration for Chesapeake Bay. Marine Ecology Progress Series 116, 217-231.

Smith, S., Herman, J., Cronin, T., Schwarz, G., Langland, M., Patison, K., Linker, L., 2003. Chapter 7: Integrated approaches to sediment studies. In: Langland, M., Cronin, T. (Eds.), A Summary Report of Sediment Processes in Chesapeake Bay and its Watershed. United States Geological Survey, New Cumberland, Pennsylvania, pp. 80-98.

Stachowicz, J.J., Terwin, J.R., Whitlatch, R.B., Osman, R.W., 2002. Linking climate change and biological invasions: Ocean warming facilitates nonindigenous species invasions. Proceedings of the National Academy of Sciences of the United States of America 99, 15497-15500.

Stevenson, J.C., Staver, L.W., Staver, K.W., 1993. Water quality associated with survival of submersed aquatic vegetation along an estuarine gradient. Estuaries 16, 346-361.

Sullivan, B.K., Van Keuren, D., Clancy, M., 2001. Timing and size of blooms of the ctenophore Mnemiopsis leidyi in relation to temperature in Narragansett Bay, R.I. Hydrobiologia 451, 113-120.

Swaney, D.P., Sherman, D., Howarth, R.W., 1996. Modeling water, sediment and organic carbon discharges in the Hudson-Mohawk basin: coupling to terrestrial sources. Estuaries 19,833-847.

Tebaldi, C., Smith, R.L., Nychka, D., Mearns, L.O., 2005. Quantifying uncertainty in projections of regional climate change: a Bayesian approach to the analysis of multimodel ensembles. Journal of Climate 18, 1524-1540.

Teng, H., Washington, W.M., Meehl, G.A., 2007. Interannual variations and future change of wintertime extratropical cyclone activity over North America in CCSM3. Climate Dynamics, 1-14. doi:10.1007/s00382-007-0314-1.

Thom, R.M. 1996. $\mathrm{CO}_{2}$-Enrichment effects on eelgrass (Zostera marina L.) and bull kelp (Nereocystis luetkeana (mert.) P \& R.). Water, Air, \& Soil Pollution 88, 383-391.

Titus, J.G., Richman, C., 2001. Maps of lands vulnerable to sea level rise: modeled elevations along the US Atlantic and Gulf coasts. Climate Research 18, 205-228.

Tortell, P.D., DiTullio, G.R., Sigman, D.M., Morel, F.M.M., 2002. $\mathrm{CO}_{2}$ effects on species composition and nutrient utilization in an Equatorial Pacific phytoplankton assemblage. Marine Ecology Progress Series 236, 37-43.

Trenberth, K.E., Jones, P.D., Ambenje, P., Bojariu, R., Easterling, D., Klein Tank, A., Parker, D., Rahimzadeh, F., Renwick, J.A., Rusticucci, M., Soden, B., Zhai, P., 2007. Observations: Surface and atmospheric climate change. In: Solomon, S., Qin, D., Manning, M., Chen, Z., Marquis, M., Averyt, K.B., Tignor, M., Miller, H.L. (Eds.), Climate Change 2007: The Physical Science Basis. Contribution of Working Group I to the Fourth Assessment Report of the Intergovernmental Panel on Climate Change. Cambridge University Press, Cambridge, United Kingdom and New York, NY, USA, pp. 235-336. 
Tyler, R.M., Targett, T.E., 2007. Juvenile weakfish Cynoscion regalis distribution in relation to diel-cycling dissolved oxygen in an estuarine tributary. Marine Ecology Progress Series 333, 257-269.

U.S. Environmental Protection Agency, 2008a. Effects of Climate Change on Aquatic Invasive Species and Implications for Managementand Research, EPA/600/R-08/ 014. U.S. Environmental Protection Agency, Washington, D.C., 337 pp.

U.S. Environmental Protection Agency, 2008b. A Screening Assessment of the Potential Impacts of Climate Change on Combined Sewer Overflow (CSO) Mitigation in the Great Lakes and New England Regions (Final Report), EPA/600/R-07/033F.U.S. Environmental Protection Agency, Washington, D.C., $52 \mathrm{pp}$.

U.S. Environmental Protection Agency, 2008c. A Screening Assessment of the Potential Impacts of Climate Change on the Costs of Implementing Water Quality-Based Effluent Limits at Publicly-Owned Treatment Works (POTWs) in the Great Lakes Region (External Review Draft). U.S. Environmental Protection Agency, EPA/600/R-07/034A.U.S. Environmental Protection Agency, Washington, D.C., $35 \mathrm{pp}$.

UNEP/GPA, 2006. The State of the Marine Environment: Trends and Processes. UNEP/GPA, The Hague, 44 pp.

Venterea, R.T., Lovett, G.M., Groffman, P.M., Schwarz, P.A., 2003. Landscape patterns of net nitrification in a northern hardwood-conifer forest. Soil Science Society of America Journal 67, 527-539.

Wardrop, D.H., Kentula, M.E., Jensen, S.F., Stevens Jr., D.L., Hychka, K.C., Brooks, R.P., 2007a. Assessment of wetlands in the Upper Juniata Watershed in Pennsylvania, USA using the hydrogeomorphic approach. Wetlands 27, 432-445.
Wardrop, D.H., Kentula, M.E., Stevens Jr., D.L., Jensen, S.F., Brooks, R.P., 2007b. Regional assessments of wetland condition: An example from the Upper Juniata watershed in Pennsylvania, U.S.A. Wetlands 27, 416-431.

Weisberg, S.B., Morin, R.P., Ross, E.A., Hirshfield, M.F., 1986. Eustrongylides (Nematoda) infection in mummichogs and other fishes of the Chesapeake Bay region. Transactions of the American Fisheries Society 115, 776-783.

Winter, T.C., 2000. The vulnerability of wetlands to climate change: A hydrologic landscape perspective. Journal of the American Water Resources Association 36, 305-312.

Wolock, D.M., McCabe, G.J., 1999. Estimates of runoff using water-balance and atmospheric general circulation models. Journal of the American Water Resources Association 35, 1341-1350.

Wood, R.J., 2000. Synoptic scale climatic forcing of multispecies fish recruitment patterns in Chesapeake Bay. Ph.D. thesis, Virginia Institute of Marine Science, The College of William and Mary.

Wood, R.J., Austin, H.M., 2009. Synchronous multidecadal fish recruitment patterns in Chesapeake Bay, USA. Canadian Journal of Fisheries and Aquatic Sciences 66, 496-508.

Wood, R.J., Boesch, D.F., Kennedy, V.S., 2002. Future consequences of climate change for the Chesapeake Bay ecosystem and its fisheries. American Fisheries Society Symposium 32, 171-184.

Wu, S.Y., Najjar, R.G., Siewert, J., 2009. Potential impacts of sea-level rise on the Midand Upper-Atlantic Region of the United States. Climatic Change 95, 121-138.

Zervas, C., 2001. Sea level variations of the United States, 1854-1999, NOAA Technical Report NOS CO-OPS 36. National Ocean Service, Silver Spring, MD, 66 pp.

Zhong, L., Li, M., Foreman, M.G.G., 2008. Resonance and sea level variability in Chesapeake Bay. Continental Shelf Research 28, 2565-2573. 